\title{
Signalling in science-based IPOs:
}

The combined effect of affiliation with prestigious universities, underwriters, and venture capitalists

\author{
Massimo G. Colombo ${ }^{\mathrm{a}}$, Michele Meoli ${ }^{\mathrm{b}}$, Silvio Vismara ${ }^{\mathrm{b}, *}$ \\ ${ }^{\text {a }}$ Politecnico di Milano \\ ${ }^{\mathrm{b}}$ University of Bergamo
}

\begin{abstract}
This paper studies the combined effect of affiliation with prestigious universities, underwriters, and venture capitalists on the valuation of biotech ventures at IPO and their post-IPO performance. We argue that affiliations with a prestigious universities provide affiliated firms with a quality signal in the scientific domain, resulting in performances superior to that of firms affiliated with either nonprestigious universities or non-affiliated firms. The signal differs from and is additive to those provided by affiliations with prominent venture capitalists and underwriters. Results for a sample of 254 European biotech ventures that went through an IPO between 1990 and 2009 confirm our predictions.
\end{abstract}

Keywords: IPO, signalling, valuation, underwriter, venture capitalist, academic entrepreneurship, spinoff

\footnotetext{
* Corresponding author: Silvio Vismara, Department of Economics and Technology Management, University of Bergamo, Italy; viale Marconi 5, 24044 Dalmine (BG), Italy. Ph. +39.035.2052352. Email: silvio.vismara@ unibg.it.

We would like to thank Fabio Pammolli, Paula Stephan, Frank Rothaermel and participants at the 2016 ENTFIN conference at EMLyon, at seminars at Lancaster Business School and at Politecnico di Milano for helpful comments.
} 


\section{Introduction}

When valuing initial public offerings (IPOs), prospective investors rely on signals to reduce the uncertainty generated by incomplete and asymmetrically distributed information. Coherently, the signaling theory (Spence, 1973) is the dominant approach to investigate IPO valuation in a broad field of studies, from entrepreneurial finance to strategic management. Drawing from the sociological evidence that ties to reputable actors enhance prestige (Podolny, 1993), third-party endorsements have received considerable attention as signals certifying firm quality to uninformed external investors. The underlying idea is that prestigious players value their reputation highly and will carefully avoid tarnishing it. ${ }^{1}$ In particular, the affiliation with a prestigious underwriter (UW) or a venture capitalist (VC) has been shown to be associated with better firm performance (Beatty and Ritter, 1986; Carter and Manaster, 1990; Carter et al., 1998, Megginson and Weiss, 1991). ${ }^{2}$

In this work, we are interested in science-based IPOs, of which biotech IPOs are a prominent example. In these offerings, uncertainty about firm quality has two dimensions. One dimension relates to the market potential of firms, the other to their scientific potential. The biotech industry originates from the recombinant DNA (rDNA) scientific breakthrough and firms' competitive advantage largely depends on the tacit, specialized scientific and technical knowledge embedded in the human capital of their scientists (Zucker et al., 1998). Public investors are unlikely to possess the requisite scientific knowledge to independently assess the innovativeness of the product and technologies biotech firms are developing (Junkunc, 2007). In addition, biotech firms are reluctant to diffuse information about their research because of the risk of expropriation of their proprietary knowledge (Deeds et al., 1997; Janney and Folta, 2003). In such settings, the literature has expanded to consider specific signals, such

\footnotetext{
${ }^{1}$ An extensive literature has also examined the role of internal signals of firm quality, such as corporate governance characteristics (Certo, 2003) or the composition of the top management team (Higgings and Gulati, 2006; Pollock and Gulati, 2007), as well as offer (Leland and Pyle, 1977) and ownership structure (Brav and Gompers, 1997; Fischer and Pollock, 2004). In this paper, we control for internal signals and focus our attention on the interaction between external signals.

2 The IPO literature has also considered other financial intermediaries involved in the going public process, such as topquality auditors (Beatty, 1989) and rating agencies (Khurshed et al., 2014), finding that they are less effective certification mechanisms.
} 
as the affiliations of firms' upper echelons with prominent companies (Chen et al., 2008; Gulati and Higgins, 2003) or their scientific standing (Deeds et al., 1997; Hess and Rothaermel, 2011; Higgins et al., 2011), and the establishment of alliances with prominent third-party organizations (Baum et al., 2000; Baum and Silverman, 2004; Gulati and Higgins, 2003; Pollock and Gulati, 2007; Pollock et al., 2010; Stuart et al., 1999).

In spite of the achievements of this literature, important issues have not been explored yet. First, although previous studies have considered science-based affiliations, such as upstream alliances (i.e. alliances with academic institutions and other research organizations, see Khoury et al., 2013; Pollock and Gulati, 2007), no distinction has been made depending on the prestige of the institutions to which ventures going through an IPO are associated. This is an important omission. Indeed, only prestigious endorsers incur the penalty costs arising from the loss of reputational capital if they are associated with low quality affiliates.

Second, in addition to providing a signal of firm scientific quality, affiliation with prestigious universities is likely to provide substantial benefits to affiliated firms. To disentangle the pure signaling effect of affiliation with prestigious institutions, the literature has relied on the view that the signaling effect is stronger when less information is available about firm quality. Accordingly, younger firms (e.g. Stuart et al., 1999) or firms at early funding rounds (Hoenen et al., 2014; Hsu and Ziedonis, 2013) benefit more from the signal delivered by reputable endorsers than mature firms or firms at subsequent financing rounds. Alternatively, Pollock et al. (2010) distinguish the certification from the substantive value according to the type of signal sender. In line with the argument that prestigious executives and directors mostly deliver substantive value, their accumulation results in higher IPO valuations in a linear manner. On the contrary, for prestigious UWs and VCs, assumed to primarily serve a certification function, their accumulation leads to higher valuations at a declining rate. Specific to science-based IPOs, however, a methodology to isolate the signaling value of scientific endorsements has not been proposed yet. 
Third, to alleviate information asymmetry problems, firms may simultaneously send multiple signals to potential investors. Since the degree of uncertainty that endorsers' certification can reduce is finite (Pollock and Rindova, 2003), these signals yield declining marginal benefits if different endorsers base their decisions on overlapping sets of information, and thus the signals provide replicative certification of firm quality (i.e. they are somehow redundant). However, as we mentioned earlier, firm quality in biotech IPOs is a multi-dimensional construct, as investors are interested in both the scientific potential of the products under development and their market potential. The positive effects of multiple signals on affiliated firms may thus be additive if they certify quality in different domains (in the case of biotech IPOs, the science domain, and the business and finance domain). How receivers aggregate concurrent signals has received limited scholarly attention (Connelly et al., 2011), with only a few exceptions (e.g. Pollock et al., 2010; Khoury et al., 2013).

Fourth, Spence (1973) claims that beliefs about the relationship between a given signal and firm performance must, in equilibrium, be confirmed by the post-signal experience (i.e., by superior postsignal performance of signaling firms). As remarked by Bergh et al. (2014), however, this is rarely tested in previous signaling studies.

To address these gaps, we study the entire population of 254 biotech firms that went public in Europe between 1990 and 2009. We first identify their affiliations with universities and measure the prestige of the latter in different ways, including bibliometric indicators. We find that firms affiliated with prestigious universities have higher valuations than either non-affiliated firms or firms affiliated with other universities. This evidence points to the importance of the quality of the endorser rather than the quantity of endorsements (e.g. number of alliances).

Second, we disentangle the "pure" quality signaling effect of firms' affiliation with prestigious universities from the substantial benefits it provides to affiliated firms. We do so by performing a diffin-diff approach, where the treatment consists in the affiliation to a prestigious university, and firms differ based on the scientific reputation of scientists in their upper echelons. We make the assumption 
that information asymmetries about the scientific quality of firms are smaller if firms' upper echelon includes reputable scientists, as in this latter case investors can rely on a concurrent measure of firms' scientific quality. We find that the signal provided by the affiliation with prestigious universities is stronger the weaker is the scientific reputation of scientists in the upper echelon of the focal IPO-firm. We thus deliver an original approach to isolate the signaling value of a scientific endorsement from its intrinsic value.

Third, acknowledging the multidimensional notion of firm quality in biotech IPOs, we claim that the study of the interaction between multiple signals needs to take duly into account that signals differ based on their information content, are incomplete and reduce uncertainty about firm quality along specific dimensions. As signals generated by affiliations with prestigious universities and prestigious VCs or UWs pertain to different domains, their positive effects on firms' IPO valuation is additive (i.e. the two types of signals do not substitute for each other). The results of our estimates on the interaction between signals confirm indeed that the signal provided by the affiliation with prestigious universities is recognized as beneficial by investors, independently of the certification from prestigious VCs and UWs. As a natural experiment, we also show that the signaling value of the affiliation with a prestigious university is unaffected by stringent regulatory changes in financial markets, whereas the values of affiliations with prestigious VCs or prestigious UWs decrease. This result lends support to our arguments that prestigious universities convey science-based signals, whose value is additive to the information conveyed by affiliations with prominent actors in the business and finance domains. From this perspective, our paper is particularly related to the study by Khoury et al. (2013), who similarly contend that it is important to consider IPO investors' evaluation of multiple simultaneous signals and find that establishing more alliances yields greater IPO proceeds but only when firms are paired with less prestigious UWs. Their argument, however, is based on the principle of signal substitutability, with seemingly valuable signals of quality offsetting one another's effects. We diverge from Khoury et al. (2013) in that we discriminate firms depending on whether they are affiliated with 
prestigious universities, while they consider the number of all upstream alliances established by IPOfirms. Their theory is indeed grounded in social capital arguments, whereby "obtaining more alliances is a reliable, sought-after quality signal" (Khoury et al., 2013, p. 573). As explained above, our contention is instead that firms signal their scientific quality by leveraging the prestige of the universities to which they are affiliated.

Fourth, we show that our results also hold in the long-term, providing a separating equilibrium in which firms affiliated with prestigious universities outperform both firms without affiliation and those that are affiliated with less prestigious universities. In doing so, we measure the stock price performance of firms, in line with existing studies on the long-run performance of IPOs, in terms of buy-and-hold returns. We find that firms affiliated with prestigious universities financially outperform other firms. Moreover, we document that these firms also exhibit superior post-IPO operating performance, measured by return-on-assets, and are more likely to become the target of an acquisition. This evidence further confirms the long-term relevance of the signal originated by the affiliation with prestigious universities. We thus provide empirical evidence relating to signal confirmation.

The rest of this paper proceeds as follows. Section 2 illustrates the research hypotheses. Section 3 discusses the data, variables, and methodology used in the study. Section 4 reports on the econometric results. Finally, Section 5 concludes the paper and discusses its implications.

\section{Theory and hypotheses}

\subsection{Affiliation with prestigious universities and valuation of science-based IPOs}

Studies show that the affiliation with a university has beneficial effects on affiliated firms when they go through an IPO, resulting in greater valuation (Bonardo et al., 2011). Here we focus attention on affiliation with prestigious universities and argue that, in science-based IPOs, this type of affiliation has a signaling value for potential investors, making them confident about the scientific quality of the technologies and products the focal IPO firm is developing. 
Science-based IPOs pose specific challenges to potential investors. Since the seminal work by Zucker et al. (1998), previous studies have highlighted that the competitive advantage of biotech firms is largely based on the tacit, specialized knowledge possessed by their scientists. Moreover, in the biotech industry, firms look for breakthrough innovations. Developing these innovations is a lengthy, expensive and uncertain process. Hence, firms go often through an IPO in an early stage, when they do not have a track record of products in clinical testing phases (Junkunc, 2007). In turn, potential investors generally do not possess the scientific knowledge necessary to assess the scientific potential of the technologies and products that firms are developing. As noted by Junkunc and Eckhardt (2009, p. 1673), in biotech "the mere disclosure of complex information will not expunge the asymmetry between parties unless the receiving party possesses the requisite knowledge to comprehend the complex information". The fact that biotech firms are reluctant to divulge scientific information relating to products that are in an early development stage makes information asymmetry problems even more severe, because of the concern that this knowledge may be misappropriated by other firms (Deeds et al., 1997; Janney and Folta, 2003)..

In this situation, affiliation with prestigious universities conveys a signal of the scientific quality of firms, thus resulting in greater IPO valuation. Investors are reassured by the endorsement of prestigious universities for three main reasons. First, prestigious universities enjoy a solid reputation generated by their previous scientific achievements, which they widely advertise with the aim of attracting both students and research contracts. Investors expect these universities to have superior abilities to evaluate the scientific rigor of studies and experiments, making them more inclined to consider the technology and products of affiliated firms as scientifically legitimate. For example, if academics at the University of Cambridge and at a less known university deliver a similar technology, the Cambridge academics' claim about the potential of the technology will be perceived as more reliable by investors due to the prestige differential between the two universities. Second, as scientific reputation is a fundamental asset for prestigious universities, they do their best to avoid tarnishing it. 
Hence, they hire professors and other research personnel with the expectation that they will further contribute to university's scientific achievements, and selectively screen their research projects. The substantial penalty cost that prestigious universities would incur from a loss of reputation makes investors confident about the value of the scientific knowledge on which affiliated firms rely in their R\&D activity. ${ }^{3}$ Third, investors are likely to attribute their positive perceptions of a prominent university to its affiliated firms, thereby increasing their perceived value through a 'halo effect' (Sine et al., 2003).

In sum, we expect that ventures spawned by firms affiliated with prestigious universities are valued more by investors at IPO than those of either non-affiliated firms or firms affiliated with other universities. This argument leads to Hypothesis 1:

\section{Hypothesis 1: The affiliation of a firm with a prestigious university is positively related} to IPO valuation.

We have argued above that the affiliation with prestigious universities delivers a signal of scientific quality, which results in higher IPO valuation. However, this type of affiliation also provides substantial benefits to affiliated firms. Previous studies have shown indeed that biotech firms generally maintain close links with universities (Audretsch and Stephan, 1996; Liebeskind et al., 1996). Biotech firms that in-license state-of-the-art knowledge from universities are more likely to craft revenuegenerating commercial alliances with pharmaceutical firms (Stuart et al., 1999). Firms affiliated with prestigious universities are in an ideal position to in-source the knowledge generated by these institutions, because of the social links of their upper echelons. They also have easier access to the state-of-the-art university laboratories and can benefit from the effective administrative and legal support they provide to affiliated firms. Therefore, one may argue that the positive effect on IPO

\footnotetext{
3 It is important to stress that affiliation with other (i.e. non-prestigious) universities does not have a similar signaling effect of firms' scientific potential. IPO firms would not be able to leverage the reputation of the academic institutions to which they are affiliated, and in absence of the penalty costs from false signaling, affiliation does not have any quality signaling effect.
} 
valuation generated by affiliation with prestigious universities is to be traced to these substantial benefits, rather than to a signal of scientific quality.

Disentangling the pure signaling effect of affiliation with prestigious institutions from the associated substantial benefits is a challenging task. Here, we take inspiration from previous works that have emphasized that the signaling effect of affiliations with prestigious institutions is weaker when more information about firm quality is available (Stuart et al., 1999). Considering the key role of prestigious scientists for the birth and development of biotech firms (Audretsch and Stephan, 1996; Zucker et al., 1998), we argue that the uncertainty perceived by potential IPO investors about the scientific potential of the technologies and products biotech firms are developing is lower when firms' upper echelon includes prominent scientists. Consistently, Higgins et al. (20011) find that biotech firms that have a Nobel prize winner in their upper echelon enjoys better valuation at IPO. We therefore expect the signaling effect of the affiliation with prestigious universities to be weaker if firms' upper echelon includes reputable scientists. Below, we explain our idea in greater detail.

High quality teams and ideas are likely to stem from prestigious universities. However, biotech firms can also derive substantial benefits from their affiliation with prestigious universities, and the more prestigious the universities the larger these benefits. Independently of whether biotech firms are affiliated with prestigious universities or not, they may have in their upper echelons prominent scientists. If they do, the uncertainty perceived by potential IPO investors about the scientific quality of the focal firm will be limited, while it will be higher if firms' upper echelons are non-prominent (i.e. not yet recognizably accomplished) scientists. The latter case provides the opportunity to isolate the signaling effect of affiliation with prestigious universities. The "pure" signaling effect is indeed stronger for firms characterized by scientists with lower reputation, because larger uncertainty surrounds the scientific quality of these firms. Hence, we expect the signal provided by the affiliation with prestigious universities to have a stronger effect on firms' IPO valuation, the lower the reputation of scientists in firms' upper echelons. On the contrary, the substantial benefits generated by this 
affiliation are likely to be largely independent of the scientific reputation of individual scientists in firms' upper echelons. From these arguments, we derive hypothesis H2.

Hypothesis 2: The positive effect of the affiliation of a firm with a prestigious university on IPO valuation is higher when the prestige of scientists in its upper echelons is lower.

\subsection{Multiple signals of biotech IPOs: the combined effect on IPO valuation of affiliations with} prestigious universities, underwriters, and venture capitalists

Firms going public do so with an investment bank that underwrites their shares. The finance and entrepreneurship literature has established that the endorsement of prestigious UWs has a positive effect on the success of IPOs (Beatty and Ritter, 1986; Carter and Manaster, 1990; Carter et al., 1998). Endorsement by prestigious UWs, as does any type of endorsement, has a signaling value. The above discussed matching mechanisms between prestigious universities and their affiliated firms apply to the underwriting markets, with prestigious UWs less likely to undertake speculative issues. Reputable UWs prefer lower-risk IPOs due to the legal liabilities and potential loss of reputational capital associated with IPOs (Beatty and Ritter, 1986). Dealing with more robust companies also increases investment banks' hopes that such relationships will lead to involvement in larger deals. Indeed, when performing seasoned equity offerings, companies going public tend not to switch to a different investment bank from the one which handled the IPO (Krigman et al., 2001), which would explain why reputable UWs are associated with better performing companies. Another explanation of this association is that top-tier investment banks have better access to the most promising start-ups and/or are better at 'picking winners'.

Insofar, as the signaling values of different affiliations relate to different domains, they are likely to generate additive effects for potential investors at IPO. We expect that this situation applies to affiliations with prestigious UWs and universities. The scientific knowledge that characterizes prestigious universities is hardly related to the command of the financial techniques, where prestigious UWs excel. Affiliations with prominent universities signal the scientific rather than the financial 
quality of the affiliated firms, and thus play a certification role in a domain that is perceived by investors as being different from that of the prestigious UWs. We therefore expect that the positive effect of the affiliation with prestigious universities does not overlap with those of the affiliation with prestigious UWs.

The certification delivered to affiliated firms by prestigious VCs works similarly to that delivered by prestigious UWs. As with hiring top investment banks as UWs, the affiliation with a prestigious VC creates a perception in the market that the IPO firm must be of good quality. Prestigious VCs generally conduct extensive due diligence and implement effective contracting (e.g. Kaplan and Stromberg, 2001). Investors will therefore be willing to pay more for taking an equity position in a firm whose quality is certified by an affiliation with a top VC. Coherently, empirical studies find that VC-backed IPO firms outperform their non-VC-backed counterparts (Brav and Gomper, 1997; Ritter, 2015). More importantly, the prestige of the backing VCs is associated with higher valuations at the IPO (Chemmanur et al., 2011; Nahata, 2008).

Since the ranges of UW and VC activities, though different, are both related to finance and business, there is at least a partial overlap in their certifications. Also, top VCs are frequent players in IPO markets and provide a continuous deal flow to the investment banks they work with (Bradley et al., 2015). Thus, prestigious VCs and UWs are often found together with declining marginal effects on firms' IPO valuations (Bradley et al., 2015; Liu and Ritter, 2011; Pollock et al., 2010). In other words, there is signal substitutability between the two, rather than signal complementarity.

Conversely, we posit that the signal provided by the affiliation with prestigious universities does not overlap with that provided by the affiliation with prestigious VCs. As mentioned earlier, the certification delivered by prestigious universities lies in the realm of science, while that of prestigious VCs, though not as finance-oriented as that of UWs, relates to the business domain. Hence, there is again no overlap. 
The above arguments about the affiliation with prestigious UWs and prestigious VCs lead to our third and fourth hypotheses:

Hypothesis 3: The affiliations of a firm with a prestigious university and a prestigious underwriter are related to IPO valuation in a positive, additive, manner.

Hypothesis 4: The affiliations of a firm with a prestigious university and a prestigious venture capitalist are related to IPO valuation in a positive, additive, manner.

\subsection{Effects on long-run performance}

Beliefs about the relationship between a signal and productivity must, in equilibrium, be confirmed by subsequent experience (Spence, 2002). In Spence's (1973, p. 360) words (applied to the job market), "an equilibrium can be thought of as a set of employer beliefs that generate offered wage schedules, applicant signalling decisions, hiring, and ultimately new market data over time that are consistent with the initial beliefs". In the context of biotech IPOs, this means that if the affiliation with prestigious universities serves as a quality signal, the signaling value becomes confirmed if the affiliated firms subsequently outperform their peers who lacked this affiliation.

Accordingly, recent management papers (Bergh et al., 2014; Connelly et al., 2011) maintain that applying signaling theory requires testing for the presence of a separating equilibrium. This, in turn, requires going beyond the receiver's reaction to a signal (in our case, the valuation at the IPO) to study whether the expectation associated with the presence of a signal (in our case, higher valuation for IPO firms affiliated with more prestigious universities, VCs, and UWs) is confirmed with postsignal findings (in our case, better long-run performance). Our arguments imply that prestigious universities create a separating equilibrium because investors believe that they will not be associated 
with low-quality firms. Therefore, a necessary equilibrium condition is that investors are willing to pay extra for affiliated firms at the IPO insofar as these firms outperform in the long run. ${ }^{4}$

Starting with the seminal study by Ritter (1991), a vast literature has found that IPOs underperform in the long run. Several economic and behavioral explanations have been brought forward to explain this anomaly. For instance, the windows-of-opportunities theory predicts that, when investors are overly optimistic about the potential of certain industries, firms may take advantage of this window of opportunity by timing their IPO and benefitting from very high valuations (Loughran and Ritter, 1995). This inevitably results in poor performance in the long run, as market enthusiasm starts to fade and stock prices are progressively adjusted. In the long run, information asymmetry tends to decrease, and the market corrects temporary inefficiencies. Upwardly biased valuations will therefore result in a downward adjustment of the issuer's stock price over time. The necessary condition for this to happen is the primary market's inability to detect overvaluation.

These market-efficiency arguments (Fama, 1970) apply to our research setting. If the signal sent by third-party endorsement is actually not related to firm quality, its higher initial valuation will mean-revert in the long-run. As long as investors are not able to notice it immediately, overvalued IPO shares will be placed on the market (which would not be possible in an efficient market), with a subsequently stronger underperformance. ${ }^{5}$ If, instead, the affiliation with a prestigious university does signal quality, affiliated firms will outperform in the long-run. We thus propose the following hypothesis:

\footnotetext{
${ }^{4}$ These arguments can also be found in the theoretical literature on signaling theory and market equilibria. Cadsby et al. (1990) show, for instance, how high-quality firms can exploit the opportunity to use a signal to break a pooling equilibrium and generate a separating equilibrium in financial markets. Note that we do not take into account developments after IPO, as this is not coherent with the value-relevance of signals for IPO investors. A signal must be observable at the moment in which the decision is taken. Like investors, we observe firms at the time of their IPO, and forecast future returns based on the information released at that moment. For the affiliation with a prestigious university to serve as a signal, such affiliation should be associated to superior long-run performance, i.e. with a lower probability of occurrence of negative outcomes. If firms affiliated with prestigious universities show the same probability of clinical trials fall or other negative outcomes, than the signal is not effective in discerning the quality of firms.

${ }^{5}$ If, instead, the signal is false (i.e. if affiliated firms are not better than non-affiliated ones) and the market is efficient, there is a second pure strategy equilibrium in which the investors refuse to believe the signal. For firms affiliated with prestigious universities, this would imply that there will be few references to their affiliation in IPO prospectuses.
} 
Hypothesis 5: The affiliation of a firm with a prestigious university is positively related to post-IPO performance.

The results reported by Carter et al. (1998) document that IPOs with a prestigious UW have higher long-run abnormal returns. Similarly, Brav and Gompers (1997) find that VC-backed IPOs have higher returns, while Nahata (2008) shows that VCs reputation is positively related to the performance of their portfolio companies. For the same reasons reported in the previous section relating to the additionality of the signals conveyed by affiliations with prestigious universities, UWs and VCs, we expect that the positive effects of affiliation with prestigious universities on firms' long-run performance are additive to those generated by affiliations with prestigious UWs and VCs. We thus propose the following hypotheses:

Hypothesis 6: The affiliations of a firm with a prestigious university and a prestigious underwriter are related to post-IPO performance in a positive, additive, manner. Hypothesis 7: The affiliations of a firms with a prestigious university and a prestigious venture capitalist are related to post-IPO performance in a positive, additive, manner.

\section{Research design}

\subsection{Data and sample}

The main challenge of an IPO is convincing a wide variety of stakeholders that the firm has long-term potential. The company's primary tool for communicating information and signaling quality to prospective investors at this stage is the offering prospectus. Since owners and managers are legally accountable for the information disclosed in these official documents, they are considered reliable in the strategy and entrepreneurship research (Shrader and Siegel, 2007). This study therefore relies on information in the offering prospectus to determine a firm's affiliation. In particular, companies going public are required to describe their history and report the curriculum vitae of their board and upper 
echelons (Higgins and Gulati, 2006). We refer to these sections to identify university-affiliated firms, namely companies that were either founded by faculty members based on their own research or created specifically to capitalize on academic research (Bonardo et al., 2011; Shane, 2004). Information on UWs and VCs is reported in the front page of the prospectus and in the ownership structure section, respectively. ${ }^{6}$

We analyze the biotech firms that went public in Europe between 1990 and 2009. European IPOs are obtained from the EURIPO database, which has been used in previous IPO studies (e.g. Chambers and Dimson, 2009; Judge et al., 2015). This dataset provides prospectuses and other detailed information on all companies that have gone public in Europe. Based on these data, our sample comprises 254 biotech companies. $^{7}$ Though the firms in our sample are all biotechnology firms, they compete in different industry niches. To account for sectoral differences, we included indicator variables representing participation in different biotechnology segments. Following Stuart et al. (1999), we included four categorical variables to indicate whether the focal venture operated in any of these four segments: Immunology, Diagnostic, Genetics, Protein Engineering and Investigation New Drug. Moreover, we added two categories dedicated to Instruments and Services.

\footnotetext{
${ }^{6}$ In order to be effective, signals need to be observable and costly. The fact that we rely on information published in IPO prospectuses assures the observability condition, as potential investors carefully scrutinize these documents to assess the prospects of an equity position. While signals are often sent intentionally, parties may also send signals without being aware of it (Janney and Folta, 2003; Spence, 2002). In our case, although the affiliation with a university is genetic, the observability of this condition is something that the entrepreneurs can actively influence. In a number of prospectuses, the affiliation with a prestigious university is made very explicit in various sections - not only those reporting the curricula of the founders but also those dedicated to the history of the firm or its R\&D strategies. Typical sections that report such information are 'History and background', 'Management', 'Directors', and 'Research and Development Programmes' in the UK; 'Historique du Groupe', 'Recherche et développement', and 'Ressources humaines' in France; 'Gründung' 'Organe der Gesellschaft', and 'Forschung und Entwicklung' in Germany; 'Storia ed evoluzione dell'attività', 'Politica di ricerca e sviluppo', 'Attività svolte dai componenti del Consiglio di Amministrazione', and 'Struttura organizzativa' in Italy. Our prospectus-based identification of university affiliations is therefore defined with regard to what is actually observable by investors, as our research design requires. As a second requirement, signaling must be less costly for parties of higher quality. For the reasons reported in our theoretical section, low-quality firms are less likely to be affiliated with prestigious universities, VCs, and UWs. It is the third party that bears most of the signaling costs since it is their reputational capital at stake.

${ }^{7}$ We identify biotech firms using code 4573 of the Industry Classification Benchmark (ICB), which comprises Healthcare (45), Pharmaceuticals \& Biotechnology (7), and Biotechnology (3). The ICB is the official industry classification adopted by European stock exchanges.
} 
This sample of firms and the subsamples of firms affiliated with universities and prestigious universities (namely, universities with a value of PRESTIGE-UNI, as defined in Section 3.2.2, above the median value, calculated in the group of firms affiliated with a university) and disaggregated by country, age, and IPO year, are described in Table 1. In total, 65 IPOs are affiliated with universities, meaning that one out of every four biotech companies going public in Europe is university-based. Predictably, the UK dominates this subsample of university-affiliated IPOs, with 38 university-based IPOs (58.5\%), as well as the subsample of IPOs affiliated with prestigious universities (66\%). The UK has the most highly developed stock exchange in Europe; it also has a flourishing biotech industry, and its university system is probably Europe's most prestigious and entrepreneurial. Finally, firms affiliated with prestigious universities went public earlier than other firms: $61 \%$ of them were 5-year old or younger at the time of the IPO, while the same figure for the entire sample of firms is $36 \%$.

\section{[INSERT TABLE 1 AROUND HERE]}

\subsection{Variables}

\subsubsection{Dependent variables}

Our empirical analysis investigates the determinants of the market's initial valuation of biotech ventures. For this purpose, we rely on Tobin's Q, a robust indicator of the perceived future value of a firm, i.e. the ratio of market value of assets, calculated as the sum of the book value of assets and the market value of common stock (calculated at offer prices) less the book value of common stock, over book value of assets. Indeed, economic theory assumes that the difference between market value and book value is the present value of a company's future abnormal earnings.

To test the long-run effects of affiliation with prestigious universities, we use three different measures. Financial performance is measured using three-year Buy-and-Hold Abnormal Returns (BHARs). These are calculated, as in Loughran and Ritter (1995), using monthly returns from the beginning of the holding period until the minimum of the end of the holding period or the delisting date, as follows: 


$$
B H A R_{i}=\left[\prod_{t=1}^{\min (T, \text { delist })}\left(1+R_{i . t}\right)\right]-\left[\prod_{t=1}^{\min (T, \text { delist })}\left(1+R_{M, t}\right)\right]
$$

where $R_{i, t}$ is the return on stock $i$ at time $t, T$ is the time period in which the BHAR is to be determined, and $R_{M, t}$ is the raw return of the FTSE Euromid index, excluding dividends. As in Vismara et al. (2012), the holding period starts from the twenty-second day of trading, as UWs are sometimes stabilizing prices during the first 21 days. Since $R_{i, t}$ includes dividends and $R_{M, t}$ doesn't, the expected BHAR $\mathrm{R}_{\mathrm{i}}$ may be positive rather than 0 in an efficient market.

We measure operating performance by the 3-year-average return-on-assets (ROA), calculated by using the ratio between EBIT (Earnings Before Interest and Taxation) and Total Assets, in the three years following the IPO.

Following the IPO, acquisitions by incumbent firms are mechanisms to finalize the technology transfer process started in a research institute (Meoli et al., 2013). Hence, we also look at the probability of a focal firm to be the target of an acquisition as a measure of post-IPO success. Our measure, here, is $M \& A$ target, a dummy variable equal to 1 if the firm has been the target of an acquisition within 5 years from the IPO. The source of information on M\&A deals is the database Thomson One Banker Deals.

\subsubsection{University affiliation and university prestige}

The University affiliation dummy is equal to 1 for firms affiliated with a university and 0 otherwise. University-affiliated firms are identified as companies that were either founded by faculty members based on their own research or created specifically to capitalize on academic research. An example of text identifying university affiliation is 'The Company was formed in 1996 at Brunel University Science Park, Uxbridge, to research and develop a number of technologies... and to make use of Dr. [name omitted]'s experience'.

The prestige of universities (PRESTIGE-UNI) is measured by resorting to a bibliometric indicator, namely the total number of citations (in thousands) received up to the year before the IPO 
by all papers ("articles") published by the parent university in the twenty years before the IPO year in the following biotech-related disciplines: Medicine; Biochemistry and Genetics; Nursing; Dentistry; Chemistry; Pharmacology, Toxicology and Pharmaceutics; Agriculture and Biological Sciences; Neuroscience; Immunology and Microbiology; Veterinary; Health professions; Chemical engineering. Following Gittelman and Kogut (2003), in regression analysis, raw citations are normalized by the mean and standard deviation of citations received by all sampled articles that were published in a given year. Normalizing raw citations by year allows citations to be summed across years for each university. The source of information for citation is Scopus, Elsevier's abstract and citation database of peerreviewed literature. We also use alternative prestige measures as robustness checks (see Table A6 in the Appendix).

Table A1 in the Appendix reports the list of the 20 top European universities included in our sample (i.e. with at least one IPO firm affiliation) according to our main prestige indicator, measured at the time of each IPO. The universities of Cambridge and Oxford are at the top of this league, in first and third position. They back four and seven IPOs, respectively. In between, in position 2, we have the Swedish Karolinska Institute, backing only one IPO in our sample.

\subsubsection{Scientist prestige}

As in several previous studies on biotech firms (e.g., Audretsch and Stephan, 1996; Zucker et al., 1998), the prestige of scientists involved in the upper echelon of each IPO firm (PRESTIGE-SC) is measured by resorting to a bibliometric indicator. We calculate the total number of citations (in thousands) received up the year before the IPO by all papers ("articles") published by members of the upper echelon of a focal IPO firm in the twenty years before the IPO year in the biotech-related disciplines, as defined for university prestige. Raw citations are normalized as illustrated above. The 
source of information for citation is Scopus. We also use alternative measures of scientists' prestige as robustness checks (see Table A6 in the Appendix). ${ }^{8}$

\subsubsection{Venture capital affiliation and prestige}

The VC backing dummy is equal to 1 for firms backed by VCs at the time of the IPO and 0 otherwise. VC firms are identified as in Vismara et al. (2012) among firms with institutional shareholders focusing on start-up financing. This information comes from a detailed examination of the directors' associations and 'Other significant shareholders' section of the IPO prospectuses. It covers the last three years prior to the IPO. To identify VC firms, several sources were used, including the lists of members of national associations such as the European Private Equity and Venture Capital Association (EVCA), the British Venture Capital Association (BVCA), the Association Francaise des Investisseurs en Capital (AFIC), the Bundesverband Deutscher Kapitalbeteiligungsgesellschaften (BVK), the Associazione italiana del private equity e venture capital (AIFI), and the National Venture Capital Association in the U.S. (NVCA). We also used directories such as Pratt's Guide to Venture Capital Sources and the Venture Capital Resource Directory. Finally, we also included Venture Capital Trusts (VCTs) managed by established VC firms.

The operationalization of VC prestige is not well defined in the literature, and no commonly recognized measure exists. In the context of IPOs, research had not differentiated among VCs by reputation until recently (see e.g. Loughran and Ritter, 2004). VC reputation has been considered through different measures, such as the reputational rank of the lead UWs (i.e. the Carter-Manaster [1990] rankings associated with a VC in prior IPOs [Baker and Gompers, 2003]); the number of investments the VC had made in a start-up's industrial segments (Hsu, 2004); past VC fund returns (Kaplan and Schoar, 2005); past rounds of VC investment (Sorensen, 2007); and the degree of specialization by individual venture capitalists at a VC firm, as measured by the Herfindahl-

\footnotetext{
${ }^{8}$ Higgins et al. (2011) argue that the presence of a Nobel laureate affiliated with a firm going through an IPO reduces information asymmetries relating to the scientific quality of the focal firm. Here we are not able to use this indicator of scientific prestige as we do not have enough observations of firms with Nobel prize laureates in their upper echelon.
} 
Hirschman Index, based on all previous investments in each industry (Gompers et al., 2009). Only recently studies have examined the impact of VC reputation on the probability of successful IPOs and post-IPO firm performance. Nahata (2008) uses a cumulative IPO market share measure in prior years based on firms' capitalization. Lee et al. (2011) introduce the LPJ VC reputation index, a multi-item, time-varying index of indicators of VC firm reputation, calculated annually for the period 1990-2010. ${ }^{9}$

In our study, the prestige of VCs (PRESTIGE-VC) supporting a focal IPO firm $i$ is measured, similarly to Nahata (2008), as the cumulative market capitalization of IPOs backed by the same VC over the cumulative market capitalization of all IPO firms in our sample that went public before firm $i$. Our measure of prestige is time-varying for those VCs supporting more than one IPO in our sample. We also use alternative prestige measures as robustness checks (see Table A6 in the Appendix).

Table A2 in the Appendix reports the list of the 20 top VCs included in our sample (i.e. with at least one VC-backed biotech IPO). The UK-based 3i is by far the most prestigious VC in Europe's biotech sector.

\subsubsection{Underwriter affiliation and prestige}

The prestige of the UW (PRESTIGE-UW) taking public a focal IPO firm $i$ is measured as the capital raised by the UW taking public all the companies in the sample that went public before firm $i$, divided by the capital raised by all the IPOs in the sample taking place before the IPO of firm $i$. Only lead and co-lead UWs are considered. When more than one UW underwrites an issue, the proceeds (and number of IPOs) are split equally among all lead banks, as in Aggarwal et al. (2002) and Abrahamson et al. (2011); this is rare in Europe (Migliorati and Vismara, 2014). UWs that have been acquired during the sampling period are treated as part of the new parent.

Table A3 in the Appendix reports the list of the 20 top UWs included in our sample (i.e. with at least one European biotech IPO underwritten between 1990 and 2009). Morgan Stanley,

\footnotetext{
${ }^{9}$ The variables included in the LPJ VC reputation index are the following: average of the total dollar amount of funds under management over the prior five years; average of the number of investment funds under management in the prior five years; number of start-ups invested in over the prior five years; total dollar amount of funds invested in start-ups over the prior five years; number of companies taken public in the prior five years; and VC firm age.
} 
Commerzbank, and Goldman Sachs are at the top of this league. While Morgan Stanley and Goldman Sachs are international top-tiers, Commerzbank operates almost entirely in a single country, Germany (Abrahamson et al., 2011). For this and other national champions (e.g. Mediobanca in Italy), their reputations are supposedly high in domestic IPO markets but lower abroad. Existing measures of UW reputation are tailored to the U.S. market, where the same established investment banks typically handle IPOs on both the NYSE and NASDAQ. The widely used Carter-Manaster rankings do not grade the reputations of the UWs involved in $67.5 \%$ of the IPOs in Europe. The European IPO market is indeed fragmented into several domestic markets, and most UWs operate almost exclusively in a single country. ${ }^{10}$ For this reason, we perform a number of robustness checks with alternative measures of UW prestige (see Table A6 in the Appendix).

\subsubsection{Signal matching and sequentiality}

University-affiliated firms have a special attractiveness for VCs (Wright et al., 2006), and one can expect that firms spawned from prestigious universities find it easier to obtain financing from prestigious VCs or backing from prestigious UWs. Thus, the VC and UW variables are constructed, following Pollock et al. (2010), in order to take into account potential matching between the signals conveyed by affiliation with prestigious universities, VCs and UWs. In our research setting, signals are sequential, as the affiliation to a university is determined at the establishment of the firm, while the VC comes in before the IPO, and the UW intervenes at the IPO. Given this sequentiality, PRESTIGE$V C$ is measured as the residuals after regressing the variable against University affiliation, PRESTIGEUNI, PRESTIGE-SC, and country and year dummy variables (we do the same for VC backing). PRESTIGE-UW is measured as the residuals after regressing the variable against University affiliation, PRESTIGE-UNI, PRESTIGE-SC, VC Backing, PRESTIGE-VC, and country and year dummy

\footnotetext{
${ }^{10}$ See Migliorati and Vismara (2014) for a description of European IPO underwriting markets and a discussion of related rankings.
} 
variables. The auxiliary regressions employed for the estimations of residuals are reported in Table A10 in the Appendix.

\subsubsection{Control variables}

In all our regressions, we include firm and market indicators as control variables, in line with previous studies on the valuation and long-run performance of IPOs (Ritter, 1991). Specifically, we include in all our specifications a set of controls for (1) the general characteristics of the firm and of its offer, (2) firms' upper echelons, and (3) inter-firm relationships. Details on all variable definitions and data sources are reported in Table 2. Variables are defined following previous papers (see, for instance, Bonardo et al., 2011).

The first set includes the general characteristics of the firm that may influence our dependent variables. Firm size is measured as inflation-adjusted sales in the year prior to the IPO in 2008 millions of Euros, using Purchasing Power Parities (EU27=1). For continental European firms, most accounting information has been reported in Euros since 1999. For earlier years, we use yearly average exchange rates between the ECU and national currencies to obtain a Euro equivalent. The exchange rate used for companies based in non-Euro countries is the average of the year of the IPO. Natural logarithms are used in the regressions. Age at the time of the IPO is measured in years since incorporation. Natural logarithms of $($ Age +1$)$ are used in the regressions. Profitability and Leverage are measured as return on assets and the ratio of debt to total assets in the year prior to the IPO, respectively. The Dilution ratio is the number of shares offered at listing over the number of shares outstanding before the IPO. The Participation ratio is the percentage of the offer made of shares sold by existing shareholders. We also include, as a measure of innovation activity ${ }^{11}$, the variable Patents, measured as the number of registered patents as reported by the US and the European Patent Office issued to the focal firm up to

\footnotetext{
${ }^{11}$ Approximately half of the firms in our sample report R\&D investments in their balance sheets. We tested whether the ratio between $R \& D$ investments and assets could influence our results on this subsample, but we could not identify a significant change in our results. The variable has therefore been dropped from the analysis.
} 
the date of the IPO (sources are EURIPO, EPO, and USPTO). Natural logarithms are used in the regressions.

The second group of control variables comprises upper echelon (UE) measures. UE size is the number of board members and top managers. Natural logarithms are used in the regressions. UE with $P h D$ is the proportion of upper echelons comprising professors and $\mathrm{PhDs}$. UE with MBA is the proportion of upper echelons with MBAs. UE with business experience is the proportion of upper echelons with experience managing biotechnological or pharmaceutical companies. Non-executive directors is the proportion of non-executive directors on the board.

The third group of control variables is related to inter-firm relationships. First, we control for IPO-firms spun out from large established firms. Corporate spinoff is a dummy variable equal to 1 for firms that are concentrated around activities originally developed in a larger parent firm (Clarysse et al. 2011) according to their IPO prospectus. Second, we include the number of alliances reported in the IPO prospectus (Baum et al., 2000; Baum and Silverman, 2004; Khoury et al., 2013). Alliances include strategic alliances, joint ventures, licensing, R\&D collaborations, marketing/distribution, and manufacturing and supply agreements, as in Guo et al. (2005). Natural logarithms of (Alliances +1$)$ are used in the regressions.

Our models also include country dummies (a set of dummy variables controlling for companies located in the UK, Germany, France, and Italy, where the reference case is 'company from other countries') and industry dummies (a set of dummy variables controlling for sub-industries in the biotech sector - immunology, diagnostics, investigation new drug, protein engineering, instruments, and services - where the reference case is 'services'). As timing matters in the valuation of IPOs, we also include year dummies.

[INSERT TABLE 2 AROUND HERE]

\subsubsection{Selection bias and the Prone to IPO variable}


Because not all firms go public, studying only IPO firms may introduce a 'success' bias that could influence our results. We use the Heckman correction model to correct for this potential sample selection bias (Heckman, 1979). Following Pollock et al. (2010), we therefore introduce in our models a first-stage regression to estimate the probability to be included in our sample for each IPO firm, with a specification in accordance to prior research on IPOs (Higgins and Gulati, 2003; Stuart et al., 1999). First, we collected from Bureau van Dijk's Amadeus database data on a random sample of 254 private biotech firms that did not go public between 1990 and 2009 but were similar to the companies in our sample according to nearest-neighbor propensity scores based on country dummies, industry dummies (see 3.2.7), size (total assets) and age. ${ }^{12}$ All these firms were 'at risk' of going public during the period covered by our study. Once the matching sample was selected, we obtained information about each private firm's age (natural logarithms of $A g e+1$ are used in the regression), total assets (natural logarithms of inflation-adjusted values are used in the regression), and number of employees (natural logarithms are used in the regression). We combined these data with similar data on our IPO firms and then used a probit regression to predict whether a firm went public during the 1990 to 2009 period. The result of this regression is reported in Table A10, Model 1, in the Appendix. Each of the predictor variables was strongly associated with the likelihood of going public (namely, total assets and number of employees are positively related, while age is negatively related). Given that only age at the IPO is a control variable in our analysis (see 3.2.7), total assets and number of employees grant the identification condition in our model (Puhani, 2000). The first stage regression was then used to calculate the Inverse Mills Ratio (i.e. the Prone to IPO variable) that we include in our second-stage regression models as an additional control.

\subsection{Sample description}

\footnotetext{
12 The matching sample of 254 firms was selected among all firm-year observations included in the Amadeus database during the sampling period.
} 
Table 3 reports the descriptive statistics for the variables employed in the empirical analysis, while the correlation matrix is reported in Table A4 in the Appendix. The average firm in our sample received a valuation at the IPO (in terms of Tobin's Q) of 3.94, experienced a -30\% BHAR and a -24\% average ROA over the next three years. Almost $60 \%$ of the sample was the target of an acquisition in the 5 years following the IPO. More than $25 \%$ of firms in the sample were university-affiliated, while $42 \%$ were backed by a VC. All measures of prestige are right-skewed, with a mean value greater than the median value; this is especially true for the university prestige variable, with a mean value of 226 and a median value of 184 .

The median age of firms when going public is seven years and their sales are around 4.4 million Euro after experiencing negative returns in the previous year $(-11 \%)$ The median leverage is $45 \%$. Biotech firms do not typically use the IPO as a divestment/diversification opportunity for the original shareholders, as can be deduced from their low participation ratios: the median value of the percentage of shares sold at IPO by existing shareholders is equal to $22 \%$. The dilution ratio, by contrast, which scales the number of shares offered over the number of shares outstanding before the IPO, is high (the median value is equal to $39.5 \%$ ), indicating that, after the IPO, almost one third of the shares will be made of newly issued shares in the hands of IPO investors.

Newly listed biotech firms are quite innovative; they have been awarded a median of seven patents. Members of firms' upper echelons often have high educational achievements: $20 \%$ hold a PhD and $12.5 \%$ hold an MBA. The ratio of non-executive directors on the board is as low as $28 \%$, consistent with the prominent advisory role, rather than agency role, of the boards of biotech IPOs (Bertoni et al., 2014).

\section{[INSERT TABLE 3 AROUND HERE]}

\section{Results}

4.1 Disentangling the signaling effect of affiliation with prestigious universities through a diff-in-diff approach 
One of the main aim of our paper is to isolate the signaling effect of the affiliation with prestigious universities from the substantial benefits it provides to affiliated firms. Building on the claim made by previous studies that the relevance of signals depends on the uncertainty surrounding firms' activities, we claim that the signaling effect of the affiliation with prestigious universities should be stronger the greater the uncertainty about firms' scientific quality. In turn, this type of uncertainty is reduced if firms' upper echelon includes reputable scientists.

In this section, we resort to a diff-in-diff approach, where the "treatment" is provided by the affiliation with a prestigious university (with the prestige of the university measured by PRESTIGE$U N I$ ), and firms differ depending on the scientific reputation of scientists in their upper echelons (with the prestige of scientists measured by PRESTIGE-SC). In particular, we consider as "treated" only the firms with PRESTIGE-UNI greater than its median value (calculated among firms affiliated to a university), and we distinguish firms according to whether PRESTIGE-SC is above or below the median value. We aim to isolate the "pure" signaling effect of affiliation with prestigious universities through the following testing procedure.

First, we focus attention on firms which do not have prestigious scientists in their upper echelons (i.e. PRESTIGE-SC below or equal to the median value). We regress the IPO valuation (Tobin's Q) of these firms on a dummy variable identifying affiliation with prestigious universities (i.e. PRESTIGE-UNI above the median value, in the group of affiliated firms) and all control variables listed in 3.2.7. The effect of the treatment PRESTIGE-UNI on Tobin's Q is defined here as $\Delta 1$. Second, we repeat the same exercise for firms with prestigious scientists in their upper echelons (PRESTIGE$S C$ above the median value) and identify the effect of the treatment PRESTIGE-UNI on Tobin's Q, that we define as $\Delta 2$. Last, we calculate the diff-in-diff $\Delta=\Delta 1-\Delta 2$, which captures the "pure" signaling effect of affiliation with prestigious universities.

Results of this exercise are reported in Table 4. Our estimates show that the affiliation to prestigious universities results in a 3.16 higher Tobin's Q for firms with non-prestigious scientists in 
their upper echelon, and a 1.64 higher Tobin's Q for firms with prestigious scientists. Both estimates are positive (although only the first value is statistically significant). These results support our Hypothesis 1, according to which affiliation with prestigious universities leads to higher IPO valuation. The difference-in-difference estimation shows a 1.52 difference between the two groups, statistically significant with $\mathrm{p}<0.05$, supporting our Hypothesis 2. Affiliation with prestigious universities has a stronger positive association with IPO valuation for firms that are not characterized by prestigious scientists in their upper echelon. These findings are further corroborated by the analysis that will be illustrated in the next Section, relying on continuous measures of PRESTIGE-UNI and PRESTIGE$S C$.

\subsection{Results of OLS regressions}

Table 5 reports the results of our OLS regressions on IPO valuations. Model 1 reports our baseline regression, including all control variables, and all prestige signals. Consistent with previous findings (see, e.g., Meoli et al., 2013), the coefficient of Firm size is negative and significant $(\mathrm{p}<0.01)$, indicating that the valuation of smaller firms benefits from higher growth opportunities. More indebted firms have higher valuations $(\mathrm{p}<0.01)$, possibly because investors value the opportunity to free-ride on the monitoring efforts of lenders (Jensen and Meckling, 1976). Evidence of a positive relation with Tobin's $\mathrm{Q}$ is also found for our measures of profitability $(\mathrm{p}<0.05)$. Variables identifying affiliation to a university (University affiliation) or to a VC are not statistically significant, showing that affiliation per se does not convey a value signal to investors. By contrast, all measures of prestige (PRESTIGEUNI, PRESTIGE-SC, PRESTIGE-VC and PRESTIGE-UW) are statistically significant.

The coefficient of PRESTIGE-UNI is equal to 0.36 (p-value<0.01). This effect is of great economic magnitude. With all continuous variables at their mean value and categorical variables at their median value, the predicted value of the Tobin's Q increases by $28 \%$, when the value of PRESTIGE-UNI increases by one standard deviation. This implies that, when evaluating a firm affiliated with a more prestigious university (i.e. PRESTIGE-UNI is at one standard deviation above 
the mean), rather than a firm affiliated with a less prestigious one (with PRESTIGE-UNI at the mean level), an investor is eager to pay 128 Euros, rather than 100, per 100 Euro of book value of assets. This evidence supports our Hypothesis 1 on the higher valuation of firms affiliated with prestigious universities.

In line with the literature, a positive and statistically significant effect is found also with respect to the other signal of prestige: PRESTIGE-SC (coefficient=0.337, p-value<0.01), PRESTIGE-VC $($ coefficient $=3.400 ;$ p-value $<0.01)$ and PRESTIGE-UW (coefficient=4.546, p-value $<0.01)$. With all remaining variables at their mean or median value, we estimate that a one-standard-deviation increase in the value of these variables leads to an increase of the predicted value of the Tobin's $\mathrm{Q}$ equal to 21.3\% (PRESTIGE-SC), 17.6\% (PRESTIGE-VC) and 12.2\% (PRESTIGE-UW).

In Model 2, we add the interaction term PRESTIGE-UNI $x$ PRESIGE-SC to the model specification. We find evidence that as predicted by Hypothesis 2, the positive association between PRESTIGE-UNI and Tobin's Q is negatively moderated by PRESTIGE-SC. Setting all continuous variables at their mean value and categorical variables at their median value, we find that a onestandard-deviation increase of PRESTIGE-UNI results in a 2.6 increase in the Tobin's Q, if PRESTIGE-SC is at its mean value minus one standard deviation. It results in a much smaller increase (equal to 0.66) if PRESTIGE-SC is at its mean value plus one standard deviation. These results are in line with the view that the signaling effect of affiliation with prestigious universities is weaker when a firm is characterized by stronger scientific prestige in the upper echelon.

In Models 3 and 4, we test for the concurrent effects of the affiliation with prestigious universities and with prestigious VCs or UWs. Looking at the moderating effect of PRESTIGE-VC (Model 3) and PRESTIGE-UW (Model 4), we find that the two interaction terms of these variables with PRESTIGE-UNI are not statistically different from 0 . These results show that the positive association between the affiliation with prestigious universities and Tobin's Q is not significantly 
weakened by affiliation with prestigious VCs or UWs. ${ }^{13}$ These results support Hypotheses 3 and 4. Lastly, in Model 5 the three interaction terms are included together. Results are very close to those illustrated above.

\section{[INSERT TABLE 5 AROUND HERE]}

\subsection{Effects on long-run performance}

Table 6 reports the results of our analysis of the long-run performance as measured by the three-year BHARs, the 3-year-average ROA, and the M\&A target dummy. For each dependent variable, we present one model with all prestige signals and all control variables, and one model which also includes the interaction terms between PRESTIGE-UNI and the other prestige variables. Apart from the dependent variable, the specifications of all models replicate those of the regressions on IPO valuation presented in Table 5, specifically in Model 1, with no interaction term, and Model 5, with the three interactions included.

In Model 1 and 2, the dependent variable is the 3-year BHAR. The four prestige variables are all significant in Model 1, with p<0.05 (PRESTIGE-UNI, PRESTIGE-SC and PRESTIGE-UW) and $\mathrm{p}<0.01$ (PRESTIGE-VC). In Model 2, where we include the interaction terms, we find evidence that PRESTIGE-SC negatively moderates PRESTIGE-UNI. Setting all continuous variables at their mean value and categorical variables at their median value, we find that a one-standard deviation increase of PRESTIGE-UNI results in a $15.2 \%$ increase in the 3-year BHAR, if PRESTIGE-SC is at its mean value minus one standard deviation; the increase is considerably smaller (equal to $8.4 \%$ ) if PRESTIGE-SC is at its mean value plus one standard deviation. Vice versa, the interaction term between PRESTIGEUNI and PRESTIGE-VC, as well as the interaction term between PRESTIGE-UNI and PRESTIGE$U W$ are not statistically significant.

\footnotetext{
${ }^{13}$ Given the (non-significant) negative signs of the coefficient referring to the interaction between PRESTIGE-UNI and PRESTIGE-VC, we computed the marginal effect of the affiliation with prestigious universities as a function of the affiliation with a prestigious VC. The marginal effect is positive and statistically significant, with $\mathrm{p}<0.10$, for all values of VC smaller than 0.5 (only 17 out of 254 observations in our sample, or $7 \%$ of the sample, are beyond this threshold). By contrast, the (non-significant) coefficient referring to the interaction between PRESTIGE-UNI and PRESTIGE-VC is positive.
} 
In Model 3 and 4, we look for corroborating results replacing the 3-year BHAR with a measure of operating performance, namely the 3-year average ROA. In Model 3, all prestige variables have positive and significant coefficients: PRESTIGE-UNI and PRESTIGE-UW with $\mathrm{p}<0.10$, while PRESTIGE-SC and PRESTIGE-VC with $\mathrm{p}<0.05$. When we include the interaction terms, in Model 4, we find evidence of a weakly significant (p-value<0.10) negative moderating effect of PRESTIGE-SC on PRESTIGE-UNI, of relatively small magnitude. A one-standard deviation increase of PRESTIGEUNI results in a $11.4 \%$ increase in the 3 -year average ROA, if PRESTIGE-SC is at its mean value minus one standard deviation and in a $8.9 \%$ increase if PRESTIGE-SC is at its mean value plus one standard deviation. The interaction terms of PRESTIGE-UNI with PRESTIGE-VC and PRESTIGE$U W$, again, are not significant.

Last, in Model 5 and 6, we model through probit regressions the probability for sample firms to be the target of an acquisition in the 5 years following the IPO. Again, in Model 5 the four prestige variables are significant, at different significance levels (PRESTIGE-UNI and PRESTIGE-UW with $\mathrm{p}<0.05 ;$ PRESTIGE-SC with $\mathrm{p}<0.10$, and PRESTIGE-VC with $\mathrm{p}<0.01)$. When introducing interaction effects, in Model 6, we find evidence that the increase of the probability of becoming the target of an acquisition within 5 years from the IPO generated by affiliation with prestigious universities is smaller the greater the scientific prestige of firms' upper echelons. When PRESTIGE-SC is set at one standard deviation below the mean value, the average marginal effect of PRESTIGE-UNI is equal to $4.6 \%$ (pvalue $<0.01$ ), while it is equal to $2.1 \%$ (p-value $<0.10$ ) when PRESTIGE-SC is set ane standard deviation above the mean value. Conversely, the average marginal effect of PRESTIGE-UNI does not significantly vary with PRESTIGE-VC and PRESTIGE-UW.

Altogether, the above results confirm the predictions of Hypotheses 5, 6 and 7 relating to the long-run performance of firms. They are in line with the view that the positive signal provided by the affiliation with prestigious universities as reflected in the post-IPO performance of firms, is less relevant when firms' upper echelons include prestigious scientists. Moreover, the affiliation of a firm 
with prestigious universities and a prestigious VC are related to post-IPO performance in a positive, additive, manner. The same applies to the affiliation of a firm with prestigious universities and a prestigious UW.

\section{[INSERT TABLE 6 AROUND HERE]}

\subsection{Natural experiment}

To determine whether the signals we analyze relating to affiliation with prominent universities, scientists, VCs, and UWs actually work as signals, we rely upon the natural experiment set by an important change in the regulation of European financial markets, which likely changed the importance of certifications. In 2002, the Sarbanes-Oxley (SOX) Act was adopted in the US to increase corporate governance standards of US-listed firms. The SOX served as a paradigm for reforms in the European Union (EU), where in the following years, reforms where approved in the different Member States to introduce the same corporate governance standards (through the so-called 'EU-SOX'). The adoption of corporate governance codes induced greater transparency and less information asymmetry, leading to greater investor confidence. Akyol et al. (2014) show, for instance, that the EU-SOX diminished, ceteris paribus, the information asymmetry between issuers and investors, as documented by a lower level of underpricing. ${ }^{14}$

We make use of this regulatory change to test whether the effects of the four prestige signals on firm valuation at IPO studied in this paper changed after the introduction of the new corporate governance codes. In particular, we take advantage of the staggered implementation of the same regulatory change across European countries to analyze its effect at different points in time. The first SOX-like regulatory change in our sample was implemented in Denmark on December 6, 2001, preceding the U.S. Most countries implemented a new regulatory setting within two years of the

\footnotetext{
${ }^{14}$ Similarly, Chhaochharia and Grinstein (2007), Iliev (2010), and Johnston and Madura (2009), among others, examine the valuation and pricing of IPO shares in the US before and after SOX was enacted; they find that, on average, underpricing is lower for IPO shares issued post-SOX.
} 
adoption of the U.S. SOX, while others as late as $2007 .{ }^{15}$ Such a large timespan allows us to better analyze the regulatory effects by mitigating the influence of potential overlapping general trends. The effect of the introduction of the EU-SOX is tested only for companies going public in regulated markets, as these regulatory changes did not affect firms going public in unregulated market, such as London's Alternative Investment Market (AIM).

The results reported in Table 7 show that, while the PRESTIGE-VC (Model 3) and PRESTIGE$U W$ (Model 4) variables turn out to significantly reduce their positive effect on IPO valuation after the introduction of the EU-SOX ${ }^{16}$, such a change is not observed for the PRESTIGE-UNI (Model 1) and PRESTIGE-SC (Model 2). In Model 3, indeed, the interaction term between the prestige of VCs with the post EU-SOX dummy is negative and significant $(\mathrm{p}<0.01)$. The same result is found in Model 4 for the interaction between the prestige of UWs and the post EU-SOX dummy $(p<0.05)$. Conversely, the coefficient of the interaction term of PRESTIGE-UNI and the post EU-SOX dummy, and the interaction term of PRESTIGE-SC and the post EU-SOX dummy (though negative), are not significant at conventional confidence levels. Moreover, an F-test rejects the null hypothesis that the effect of PRESTIGE-UNI on Tobin's Q in the post-EU-SOX period is not different from zero (Ftest $(1,203)=7.54, \mathrm{p}<0.01)$. A similar result is found with respect to the effect of PRESTIGE-SC (Ftest $(1,203)=6.96, p<0.01)$. We interpret these results by stressing the different types of information asymmetry that the prestige signals challenge. Since prestigious VCs and UWs are expected to ameliorate the uncertainty surrounding the financial quality of the firms going public, their effect is weaker after the EU-SOX, as the new corporate governance codes implied higher financial transparency for all IPOs. Conversely, since the affiliation with prestigious universities aims to reduce the uncertainty related to firms' scientific quality, its role is not substantially affected by the adoption

\footnotetext{
15 Table 1 of Akyol et al. (2014) lists the corporate governance codes adopted between 2000 and 2012 by European countries.

16 The summation of the two PRESTIGE-VC coefficients (coefficient over the full sample plus marginal post-SOX coefficient) produces 1.9, not statistically significant. The summation of the two PRESTIGE-UW coefficients (coefficient over the full sample plus marginal post-SOX coefficient) produces 1.7 , not statistically significant.
} 
of EU-SOX. The same reasoning applies to the role of the scientific prestige of firms' upper echelons. As a whole, these results provide additional evidence that the effects of PRESTIGE-UNI (as well as that of PRESTIGE-SC) do not overlap with those of PRESTIGE-VC and PRESTIGE-UW. Model 5 tests the interactions between the single signals and the EU-SOX dummy at the same time, confirming earlier results.

Last, in Model 6 and 7, the interaction between the signals and the EU-SOX dummy is tested on two subsamples, comprising firms with PRESTIGE-SC below the median value, and above the median value, respectively. In both sub-samples, the interaction of PRESTIGE-UNI and the EU-SOX dummy is not significant. Interestingly, the effect of PRESTIGE-UNI is stronger $(0.367, \mathrm{p}$-value $<0.01$ vs. 0.250 , $\mathrm{p}$-value $<0.05$ ) in the sample of firms with less prestigious scientists in their upper echelons.

\section{[INSERT TABLE 7 AROUND HERE]}

\subsection{Robustness tests}

This section describes the robustness tests with regard to (1) instrumenting the measures of PRESTIGE-VC and PRESTIGE-UW, to account for potential endogeneity; (2) alternative specifications for the definition of the prestige variables; (3) the adoption of alternative dependent variables, namely Enterprise Value/Sales and underpricing; (4) the robustness of the interactions among signals by testing the inclusion of pairs of prestige signals; and (5) the inclusion of variables related to the 'intensity' of the signals, such as university ownership and VC syndication. All results discussed in this section are reported in the additional tables available in the Appendix.

First, while in our previous analyses we took into account that the endorsements by universities, VCs and UWs enter into the game sequentially (see section 3.2.6), we aim here to provide further support to our results by implementing an alternative modelling strategy, where the potential endogeneity of prestige signals entering at a second stage is treated through an instrumental variable approach. More precisely, in Table A5 in the Appendix, we report the results of instrumental variable regressions on the valuation at the IPO, measured through Tobin's Q, of our sample firms. While the 
outcome equation is the same we used in the previous section of the paper (as in Model 5 of Table 5), we employ here additional equations to instrument as potentially endogenous variables both PRESTIGE-VC and PRESTIGE-UW. PRESTIGE-VC is instrumented by using a variable (VC EUActivity) defined as the cumulative market capitalization of non-biotech IPOs backed by the focal VC over the population of European non-biotech IPOs in the period 1990-2009. PRESTIGE-UW is instrumented by using a variable ( $U W$ EU-Activity) defined as the share of non-biotech IPOs taken public by the focal UW in the population of European non-biotech IPOs, in the period 1990-2009, as reported in the EURIPO database. Given that in our outcome variable PRESTIGE-VC and PRESTIGE$U W$ are interacted with PRESTIGE-UNI, two further instruments are created by interacting $V C E U$ Activity and $U W$ EU-Activity with PRESTIGE-UNI. The four instruments are statistically significant in the corresponding instrumental equations reported in Models 1-4 of Table A5 in the Appendix, indicating that they are positively associated with the prestige of the VCs and UWs involved in biotech IPOs. Further, VC EU-Activity and UW EU-Activity represent prior activity of VC and UW on nonbiotech markets, and are therefore unlikely to affect valuation of biotech IPO firms in the eyes of potential investors, if not through the prestige itself of VCs and UWs. This is why we support the excludability of the instrumental variables, and therefore their validity. Model 5 of Table A5 reports the outcome equations, with results in line with those reported in earlier sections ${ }^{17}$.

Second, we controlled for the robustness of our results when measuring the prestige variables with several alternative specifications. In Table A6 in the Appendix, we replicate Model 5 in Table 5, replacing one measure of prestige at a time ( 2 alternative definitions for each prestige measure). Model 1-2 include alternative measures of university prestige. PRESTIGE-UNI is defined in Model 1 according to the Annual Ranking of World Universities (ARWU) published by the Jiao Tong University in Shanghai (PRESTIGE-SC=Ranking ${ }^{-1}$ when a ranking is available, 0 otherwise); in Model

\footnotetext{
${ }^{17}$ Please consider that a first-stage equation for sample selection correction is also needed (see section 3.2.8). Hence, our model actually consists here of 6 equations, estimated with structural equation modelling techniques (GSEM command in Stata).
} 
2 by a dummy variable equal to 1 for universities listed in the Milken Ranking of universities in the biotech field, 0 otherwise. Models 3 and 4 include an alternative measures of scientists' prestige. PRESTIGE-SC is defined in Model 3 as the total number of papers ("articles") published by members of the upper echelon of a certain IPO firm in the twenty years before the IPO year in biotech-related fields (see Table 2 for the list of fields) and normalized by the mean and standard deviation of all sampled articles published per year. In Model 4 it is captured by the total number of top papers ("articles" published in Nature, Science and Cell) published by members of the upper echelon of a focal IPO firm in the twenty years before the IPO year, normalized by the mean and standard deviation of sampled top papers published per year and transformed into natural logarithms. Models 5 and 6 include alternative measures of VC prestige: PRESTIGE-VC is defined in Model 5 as the value of the LPJ Reputation Index 2001-2010 available at Timothy Pollock's website; in Model 6 it is measured by a dummy variable equal to 1 for all the VCs with above-median value of LPJ Reputation Index 2001-2010, 0 otherwise. Models 7 and 8 include alternative measures of UW Prestige. PRESTIGE$U W$ is defined in Model 7 as the share of IPOs taken public by a focal UW in sample IPOs; in Model 8 as the Carter Manaster ranking (1990). All results reported in Table A6 in the Appendix confirm our previous findings. ${ }^{18}$

Third, we also challenged our independent variables by replacing our IPO valuation measure, the Tobin's Q, with an alternative measure of valuation (see Table A7 in the Appendix). First, we rerun our analysis (Model 1 and 5 in Table 5) by using the ratio between the Enterprise Value (defined as the sum of the market value at IPO and the total value of debt in the latest balance sheet) and sales. Our results are qualitatively unchanged. Second, we replaced the Tobin's Q with the underpricing at the IPO. Underpricing is commonly used in the management literature as a proxy of uncertainty (Daily et al., 2003). In this case, in line with our expectations, the signs of the estimated coefficients for the

\footnotetext{
${ }^{18}$ In untabulated results, we also tested for the non-linearity of prestige signals by including squared values for each prestige indicators. We found weak evidence of a more-than-linear effect for the university signal (i.e. the effect on valuation provided by prestigious universities grows more than linearly with university prestige).
} 
prestige variables are negative. Moreover, the interaction between PRESTIGE-UNI and PRESTIGE$S C$ is positive, while PRESTIGE-UNI is not significantly affected by interactions with PRESTIGE-VC or PRESTIGE-UW.

Fourth, we controlled for the robustness of the interaction terms included in our analyses by running regressions where each couple (previously untested) was assessed. In Table A8 in the Appendix, we report Model 1, including the interaction between PRESTIGE-SC and PRESTIGE-VC; Model 2 including the interaction between PRESTIGE-SC and PRESTIGE-UW; and Model 3 including the interaction between PRESTIGE-VC and PRESTIGE-UW. We find that PRESTIGE-SC does not show any significant moderating effect, while the interaction between PRESTIGE-VC and PRESTIGE$U W$ is significant and negatively signed. We interpret this results as an evidence that the effects of the affiliations with prestigious VCs and UWs are perceived by investors as overlapping, with sub-additive effects on Tobin's Q. This is likely to be due to the fact that both VCs and UWs provide financial (and business), rather than scientific signals of quality to investors.

Fifth, we added to the model specification variables related to the intensity of the signals provided by universities and VCs - the ownership stake possessed by universities and the number of VCs in a syndicate (See Table A9 in the Appendix). In both cases, these variables were not statistically significant, and the results relating to our explanatory variables remain unchanged.

\section{Discussion and conclusions}

\subsection{Synthesis of results and contributions}

The aim of this study was to investigate the beneficial effects on the valuation and performance of IPO firms of the affiliation with a prestigious university, and its interaction with the affiliation with prestigious VCs and UWs. For this purpose, we have analyzed the population of European biotech IPOs in the period 1990-2009. Our results show that firms affiliated with prestigious universities exhibit higher IPO valuation and better post-IPO performance than either firms affiliated with other 
universities or non-affiliated firms. We are confident that this result is due to the signal provided by the affiliation with a prestigious university, as it is stronger the weaker is the scientific prestige of scientists in the upper echelon of the focal IPO-firm. Moreover, this effect is not substantially weakened by affiliations with prestigious VCs or UWs. Lastly, these effects are also not affected by the introduction of the EU-SOX regulation of financial markets, while this regulatory change appears to significantly weaken the positive effects engendered by affiliations with prestigious VCs and UWs.

Our results provide fresh insights into the literature on signals at science-based IPOs. In this type of IPOs, potential investors' valuation of firms is negatively influenced by uncertainty relating to both the scientific and market potentials of firms. To reduce this uncertainty, firms need to rely on multiple signals, which certify their quality in both domains. We offer three original contributions to this literature. First, we show that the affiliation with universities is a valuable signal of firms' scientific quality only if the university is prestigious. Second, we disentangle the signaling effect of affiliation with prestigious universities from the substantial benefits associated with this affiliation. Third, we highlight that the scientific endorsement of prestigious universities is a signal recognized as beneficial by investors, independently of the certification mechanisms pertaining to different domains that are provided by affiliation with prestigious VCs or UWs.

Further, our paper contributes to the literature on academic entrepreneurship (see e.g. Rothaermel et al., 2007 for a review). Most of the studies in this stream focus attention on the first steps, if not on the establishment, of university-affiliated firms, and compare their strategies and performance with those of non-affiliated firms (e.g. Colombo and Piva, 2012). In this work, we highlight the long-lasting financial benefits of affiliation with a (prestigious) university. In doing so, we extend the scope of the academic spin-off literature by considering in addition to parent universities and firms' founders, the perspective of a so-far neglected set of stakeholders, namely IPO investors. The fact that the affiliation with a prestigious university enhances the confidence of IPO investors is 
an important contribution that expands the measurement of the performance of academic spin-offs from the product to the financial markets.

\subsection{Implications for practice and policy}

This study focuses on science-based IPOs: its practical implications are first and foremost financial. Our results indicate to entrepreneurs of science-based ventures going through an IPO that it is important to signal the quality of their firms both in the scientific and business/financial domains, and that affiliations with prestigious universities, VCs and UWs indeed nicely serve this purpose, leading to greater IPO valuation. They also indicate to IPO investors that it is worth paying more to take an equity position in this type of firm at the IPO, as this asset class outperforms in the long-run.

Second, our results are of interest to those involved in technology transfer at universities. IPOs are generally considered as the most attractive exit option for academic spin-offs, as for any start-up. However, managers of technology transfer offices and entrepreneurial scientists should be aware that valuations at the IPO closely depend on the prestige of the universities to which academic spin-offs are affiliated. While public equity investors greatly appreciate an affiliation with a prestigious university, they do not give any premium to firms affiliated with non-prestigious universities, making an IPO a relatively less attractive option for this category of firms.

Third, our study has implications for policymakers. The third mission of universities is now more important in their eyes than it used to be, as testified by the policies implemented by governments and public agencies to increase the engagement of universities with economic development. The creation of academic spin-offs, together with the number of patent applications filed, is a typical indicator used by policy makers to assess the third mission performance of universities. This positive view of the role of academic spin-offs was fostered by "success stories" often based in favorable contexts such as the Silicon Valley. However, a large number of academic spin-offs have weak business models and poor growth potential (Meoli and Vismara, 2016). Our results show that market investors do not pay a premium at IPO for academic spin-offs from non-prestigious universities, and 
these firms do not overperform in the post-IPO period. These results are in line with the view that policy schemes that indiscriminately stimulate the creation of academic spin-offs are a bad move (Mustar and Wright, 2010).

\subsection{Limitations and future research directions}

As with all studies, ours has limitations. First, the generalizability of our results is limited by the boundary conditions of our empirical setting. We analyzed the population of biotech firms listed on European stock exchanges in the period 1990-2009. Our sampling was therefore limited in terms of (1) industry, (2) geography, and (3) type of transaction.

As to industry, biotechnology provides a fertile setting for this study. Biotechnology is not a separate science but rather a mix of disciplines transmuted into productive processes by coupling with such applied disciplines as chemical engineering, information technology, and robotics. Such a multidisciplinary field poses serious challenges to the valuation of IPO firms. On the other hand, biotechnology is a quite specific setting. First, the role of universities is particularly relevant in this industry because of its science-based nature. Second, VCs that operate in this industry are highly specialized and have industry-specific scouting and coaching capabilities. A similar reasoning applies to financial analysts in investment banks underwriting biotech IPOs. Future research might broaden the perspective to investigate how signals provided by universities, VCs and UWs interact in other high-tech industries like information technologies, which exhibit different characteristics relating to the above actors and the relative importance of different sources of information asymmetries (e.g. market potential versus scientific and technological potential).

A second boundary condition of our study is our European focus. Despite being a latecomer to bio-entrepreneurship, Europe's number of biotech IPOs is comparable to the one in the U.S. The relatively high number of biotech IPOs in Europe is arguably due, at least in part, to the difficult access to alternative sources of capital because of the smaller scale of the VC industry compared to that in the U.S. The role of UWs is also quite different in the two continents. Unlike in the U.S., where companies 
going public select investment banks independently of, and even before, the listing market and the same established investment banks handle IPOs on both the NYSE and NASDAQ, the European underwriting market is fragmented and local banks operating almost entirely in a single country compete with top-tier international UWs. A replication of this study in the U.S. context would allow to investigate whether our results are influenced by the different institutional characteristics of these two geographic areas.

The study of IPO firms is our third boundary condition. Challenged with convincing a wide variety of potential investors of the long-term potential of the firm, the success of an IPO is largely a matter of conveying the right signals. The focus on IPOs is therefore shared with most studies on the uncertainty-reducing power of signals from third-party endorsements. Recently, crowdfunding platforms have offered an alternative way to raise funds from a diversified set of shareholders. Crowdfunding, albeit a relatively new phenomenon, is growing rapidly around the world. Because of the specificities of the biotech sector, a number of dedicated platforms are being launched, where campaigns are often led by university-based projects. Future studies might investigate whether the affiliation with a prestigious university is perceived as a signal of scientific quality also in these markets and what bundle of signals are used by firms to attract investors. 


\section{References}

Abrahamson, M., Jenkinson, T. and Howard, J., 2011. Why Don’t U.S. Issuers Demand European Fees for IPOs? Journal of Finance 66, 2055-82.

Aggarwal, R. K., Krigman, L. and Womack, K. L., 2002. Strategic IPO underpricing, information momentum, and lockup expiration selling. Journal of Financial Economics 66, 105-37.

Akyol, A. C., Cooper, T., Meoli, M. and Vismara, S., 2014. Do regulatory changes affect the underpricing of European IPOs? Journal of Banking \& Finance 45, 43-58.

Audretsch, D.B. and Stephan, P., 1996. Company-Scientist Locational Links: The Case of Biotechnology. American Economic Review 86, 641-652.

Baker, M. and Gompers, P. A., 2003. The determinants of board structure at the initial public offering, Journal of Law and Economics 46, 569-598.

Baum, J.A., Calabrese, T., and Silverman, B.S. 2000. Don't go it alone: Alliance network composition and startups' performance in Canadian biotechnology. Strategic Management Journal, 21, 267-294.

Baum, J.A.C. and Silverman, B.S., 2004 Picking Winners or Building Them? Alliance, Intellectual, and Human Capital as Selection Criteria in Venture Financing and Performance of Biotechnology Startups. Journal of Business Venturing 19, 411-436.

Beatty R. P., 1989. Auditor Reputation and the Pricing of Initial Public Offerings. Accounting Review, 64, 693-709.

Beatty, R. P. and Ritter J. R., 1986. Investment banking, reputation and the underpricing of initial public offerings. Journal of Financial Economics 15, 213-232.

Bergh, D.D., Connelly, B.L., Ketchen, D.J. and Shannon, L.M., 2014. Signaling theory and equilibrium in strategic management research: An assessment and research agenda. Journal of Management Studies 51, 1334-1360.

Bertoni, F., Meoli, M. and Vismara, S., 2014. Board Independence, Ownership Structure, and the Valuation of IPOs in Continental Europe. Corporate Governance: An International Review 22, 116131. 
Bonardo, D., Paleari, S. and Vismara, S., 2011. Valuing university-based firms: the effects of academic affiliation on IPO performance, Entrepreneurship Theory and Practice 35, 755-776.

Bradley, D. J., Kim, I. and Krigman, L., 2015. The role of top VCs in IPO markets. Top VC IPO underpricing. Journal Corporate Finance 31, 186-202.

Brav, A. and Gompers, P. A., 1997. Myth or Reality? The Long-Run Underperformance of Initial Public Offerings: Evidence from Venture and Nonventure Capital-Backed Companies. Journal of Finance 52, 1791-1821.

Cadsby, C. B., Frank, M. and Maksimovic, V. 1990. Pooling, separating, and semiseparating equilibria in financial markets: Some experimental evidence. Review of Financial Studies 3, 315-342.

Carter, R. and Manaster, S., 1990. Initial public offerings and underwriter reputation. Journal of Finance 45, 1045-67.

Carter, R. B., Dark, F. H. and Singh, A. K., 1998. Underwriter reputation, initial returns, and the LongRun Performance of IPO Stocks. Journal of Finance 53, 285-311.

Certo, S.T., 2003. Influencing initial public offering investors with prestige: signaling with board structures. Academy of Management Review 28, 432-446.

Chambers, D. and Dimson, E., 2009. IPO Underpricing over the Very Long Run. Journal of Finance 64, 1407-1443.

Chemmanur, T. J., K. Krishnan and D. K. Nandy, 2011. How Does Venture Capital Financing Improve Efficiency in Private Firms? A Look Beneath the Surface. Review of Financial Studies 24, 4037-4090.

Chen, G., Hambrick, D. C. and Pollock, T. G. 2008. Puttin' on the Ritz: Pre-IPO enlistment of prestigious affiliates as deadline-induced remediation. Academy of Management Journal, 51, 954975.

Chhaochharia, V. and Grinstein, Y., 2007. Corporate governance and firm value: The impact of the 2002 governance rules. Journal of Finance 62, 1789-1825.

Clarysse, B., Wright, M. and Van de Velde, E., 2011. Entrepreneurial origin, technological knowledge and the growth of spin-off companies. Journal of Management Studies 48, 1420-1442. 
Colombo, M.G. and Piva, E., 2012. Firms' genetic characteristics and competence-enlarging strategies: A comparison of academic and non-academic high-tech start-ups. Research Policy 41, 7992.

Connelly, B.L., Certo, S.T., Ireland, R.D. and Reutzel, C.R., 2011. Signaling Theory: A Review and Assessment. Journal of Management 37, 39-67.

Daily, C. M., Certo, S. T., Dalton, D. R. and Roengpitya, R. 2003. IPO underpricing: A meta-analysis and research synthesis. Entrepreneurship: Theory and Practice 27, 271-295.

Deeds, D. L., Decarolis, D., and Coombs, J. E., 1997. The impact of firm-specific capabilities on the amount of capital raised in an initial public offering: Evidence from the biotechnology industry. Journal of Business Venturing, 12, 31-46.

Fama, E., 1970. Efficient Capital Markets: A Review of Theory and Empirical Work. Journal of Finance 25, 383-417.

Fischer, H. M. and Pollock, T. G., 2004. Effects of social capital and power on surviving transformational change: The case of initial public offerings. Academy of Management Journal 47, 463-481.

Gittelman, M., and Kogut, B., 2003. Does good science lead to valuable knowledge? Biotechnology firms and the evolutionary logic of citation patterns. Management Science, 49, 366-382.

Gompers, P., Kovner, A. and Lerner, J., 2009. Specialization and success: Evidence from venture capital. Journal of Economics \& Management Strategy 18, 817-844.

Gulati, R. and Higgins, M. C., 2003. Which ties matter when? The contingent effects of interorganizational partnerships on IPO success. Strategic Management Journal 24, 127-144.

Guo, R.-J., Lev, B. and Zhou, N., 2005. The Valuation of Biotech IPOs. Journal of Accounting, Auditing \& Finance 20, 423-459.

Heckman, J. J., 1979. Sample Selection Bias as a Specification Error. Econometrica 47, 53-161.

Hess, A. and Rothaermel, F., 2011. When are assets complementary? Star scientists, strategic alliances and innovation in the pharmaceutical industry. Strategic Management Journal 32, 895- 909. 
Higgins, M. C. and Gulati, R. 2003. Getting off to a good start: The effects of upper echelon affiliations on underwriter prestige. Organization Science 14, 244-263.

Higgins, M. C. and Gulati, R., 2006. Stacking the deck: The effects of top management backgrounds on investor decisions. Strategic Management Journal 27, 1-25.

Higgins, M. J., Stephan, P. and Thursby, J. (2011). Conveying quality and value in emerging industries: Star scientists and the role of signals in biotechnology. Research Policy, 40, 605-617.

Hoenen, S., Kolympiris, C., Schoenmakers, W. and Kalaitzandonakes, N., 2014. The diminishing signaling value of patents between early rounds of venture capital financing. Research Policy 43, 956989.

Hsu, D.H., 2004. What do entrepreneurs pay for venture capital affiliation? Journal of Finance 59, $1805-1844$.

Hsu D. H. and Ziedonis R. H., 2013. Resources as Dual Sources of Advantage: Implications for Valuing Entrepreneurial-Firm Patents. Strategic Management Journal 34, 761-781.

Iliev, P., 2010. The effect of SOX Section 404: Costs, earnings quality, and stock prices. Journal of Finance 65, 1163-1196.

Janney, J.J. and Folta, T.B., 2003. Signaling through private equity placements and its impact on the valuation of biotechnology firms. Journal of Business Venturing 18, 361-380.

Jensen, M. C., and Meckling, W. H., 1976. Theory of the firm: Managerial behavior, agency costs and ownership structure. Journal of Financial Economics 4, 305-360.

Johnston, J. and Madura, J., 2009. The pricing of IPOs post-Sarbanes-Oxley. Financial Review 44, 291-310.

Judge, W. Q., Witt, M. A., Zattoni, A., Talaulicar, T., Chen, J. J., Lewellyn, K., Hu, H. W., Shukla, D., Bell, R. G., Gabrielsson, J., Lopez, F., Yamak, S., Fassin, Y., McCarthy, D., Rivas, J. L., Fainshmidt, S. and Van Ees, H., 2015. Corporate governance and IPO underpricing in a cross-national sample: A multilevel knowledge-based view. Strategic Management Journal 36, 1174-1185. 
Junkunc, M. T., 2007. Managing radical innovation: The importance of specialized knowledge in the biotech revolution. Journal of Business Venturing, 22, 388-411.

Junkunc M. T. and Eckhardt, J. T., 2009. Technical specialized knowledge and secondary shares in initial public offerings. Management Science 55, 1670-1687.

Kaplan, S. and Schoar, A., 2005. Private Equity Performance: Returns, Persistence, and Capital Flows. Journal of Finance 60, 1791-1823.

Kaplan, S. N., and Stromberg, P., 2001. Venture Capitalists as Principals: Contracting, Screening, and Monitoring. American Economic Review 91, 426-430.

Khoury, T. A., Junkunc, M., and Deeds, D. 2013. The social construction of legitimacy through signaling social capital: Exploring the conditional value of alliances and underwriters at IPO. Entrepreneurship Theory \& Practice 37, 569-601.

Khurshed, A., Paleari, S., Pandè, A. and Vismara, S., 2014. Transparent bookbuilding, certification and initial public offerings. Journal of Financial Markets 19, 154-159.

Krigman, L., Shaw, W.H., Womack, K.L., 2001. Why do firms switch underwriters? Journal of Financial Economics 60, 245-284.

Lee, P.M., Pollock, T.G. and Jin, K., 2011. The contingent value of venture capitalist reputation for entrepreneurial firms. Strategic Organization 9, 33-69.

Leland H. E. and Pyle D. H., 1977. Informational asymmetries, financial structure, and financial intermediation. Journal of Finance 32, 371-387.

Liebeskind, J. P., Oliver, A. L., Zucker, L., and Brewer, M. 1996. Social networks, learning, and flexibility: Sourcing scientific knowledge in new biotechnology firms. Organization Science 7, 428443.

Liu, X., and Ritter, J. R., 2011. Local underwriter oligopolies and IPO underpricing. Journal of Financial Economics 102, 579-601.

Loughran, T. and Ritter, J. R., 1995. The New Issues Puzzle. Journal of Finance 50, 23-51. 
Loughran, T., and Ritter, J. R., 2004. Why Has IPO Underpricing Changed Over Time? Financial Management 33, 5-37.

Megginson, W. and Weiss, K., 1991. Venture capitalist certification in IPOs. Journal of Finance 46, 879-903.

Meoli, M., Paleari S. and Vismara, S., 2013. Completing the technology transfer process: M\&As of science-based IPOs. Small Business Economics 40, 227-248.

Meoli, M. and Vismara, S., 2016. University support and the creation of technology and nontechnology academic spin-offs, Small Business Economics, forthcoming. DOI: 10.1007/s11187-0169721-1.

Migliorati K. and Vismara S., 2014. Ranking Underwriters of European IPOs. European Financial Management 20, 891-925

Mustar, P. and Wright, M., 2010. Convergence or path dependency in policies to foster the creation of university spin-off firms? A comparison of France and the United Kingdom. Journal of Technology Transfer 35, 42-65

Nahata, R., 2008. Venture capital reputation and investment performance. Journal of Financial Economics 90, 127-151.

Podolny, J. M., 1993. A status-based model of market competition. American Journal of Sociology 98, 829-872.

Pollock, T. G., Chen, G., Jackson, E. M. and Hambrick, D. C., 2010. Just how much prestige is enough? Assessing the value of multiple types of high-status affiliates for young firms. Journal of Business Venturing 25, 6-23.

Pollock, T. G. and Gulati, R., 2007. Standing out from the crowd: The visibility enhancing effects of IPO-related signals on alliance formations by entrepreneurial firms. Strategic Organization 5, 339372.

Pollock, T. G. and Rindova, V. P., 2003. Media legitimation effects in the market for initial public offerings. Academy of Management Journal 46, 631-642. 
Puhani, P., 2000. The Heckman correction for sample selection and its critique. Journal of economic surveys $14,53-68$.

Ritter, J. R., 1991. The long-run performance of initial public offerings. Journal of Finance,46, 3-27.

Ritter, J. R., 2015. Growth Capital-Backed IPOs. Financial Review 50, 481-515.

Rothaermel, F. T., Agung, S. D. and Jiang, L., 2007. University entrepreneurship: a taxonomy of the literature. Industrial and Corporate Change 16, 691-791.

Shane, S., 2004. Academic entrepreneurship: University spinoffs and wealth creation. Cheltenham, UK: Edward Elgar.

Shrader, R., Siegel, D.S., 2007. Entrepreneurial team experience, strategy, and the long-term performance of high-growth technology-based new ventures. Entrepreneurship Theory and Practice 31, 893-907.

Sine, W., Shane, S., and Di Gregorio, D., 2003. The halo effect and technology licensing: The influence of institutional prestige on the licensing of university inventions. Management Science 49, 478-497.

Sorensen, M., 2007. How Smart is Smart Money? A Two-Sided Matching Model of Venture Capital. Journal of Finance 62, 2725-2762.

Spence, M., 1973. Job Market Signaling. Quarterly Journal of Economics 87, 355-374.

Spence, M., 2002. Signaling in retrospect and the informational structure of markets. American Economic Review 92, 434-59.

Stuart, T. E., Hoang, H. and Hybels, R. C., 1999. Interorganizational endorsements and the performance of entrepreneurial ventures. Administrative Science Quarterly 44, 315-349.

Vismara, S., Paleari S. and Ritter, J. R., 2012. Europe's Second Markets for Small Companies. European Financial Management 18, 352-388.

Wright, M., Lockett, A., Clarysse, B. and Binks, M., 2006. University spin-out companies and venture capital. Research Policy 35, 481-501. 
Zucker, L. G., Darby, M. R., and Brewer M. B., 1998. Intellectual human capital and the birth of the U.S. biotechnology enterprise. American Economic Review, 88, 290-306. 


\section{Table 1. Sample by type of affiliation}

Distribution of our sample of 254 biotech IPO firms by country, age at IPO and IPO year. The first column refers to the total number of firms in the sample, the second and third columns to firms (number and percentage) affiliated with a university, the fourth and fifth columns to firms (number and percentage) affiliated with prestigious universities (namely with a value of PRESTIGE-UNI, see Table 2, greater than or equal to the median value, calculated in the group of firms affiliated with a university).

\begin{tabular}{|c|c|c|c|c|c|}
\hline & \multirow[t]{2}{*}{ Total } & \multicolumn{2}{|c|}{$\begin{array}{c}\text { Firms affiliated with a } \\
\text { university }\end{array}$} & \multicolumn{2}{|c|}{$\begin{array}{l}\text { Firms affiliated with a } \\
\text { prestigious university }\end{array}$} \\
\hline & & No. & $\%$ & No. & $\%$ \\
\hline \multicolumn{6}{|c|}{ Panel A. Country } \\
\hline UK & 110 & 38 & 58.5 & 22 & 66.7 \\
\hline France & 45 & 5 & 7.7 & 1 & 3.0 \\
\hline Germany & 39 & 13 & 20.0 & 5 & 15.1 \\
\hline Italy & 10 & 1 & 1.5 & 0 & 0.0 \\
\hline Other & 50 & 8 & 12.3 & 5 & 15.1 \\
\hline \multicolumn{6}{|c|}{ Panel B. Age at IPO (years) } \\
\hline Age $<=1$ & 18 & 5 & 7.7 & 2 & 6.1 \\
\hline $1<$ Age $<=5$ & 74 & 22 & 33.8 & 18 & 54.5 \\
\hline $5<$ Age $<=10$ & 99 & 29 & 44.6 & 12 & 36.3 \\
\hline Age $>10$ & 63 & 9 & 13.8 & 1 & 3.0 \\
\hline \multicolumn{6}{|c|}{ Panel C. Year of IPO } \\
\hline $1990-2000$ & 57 & 12 & 18.5 & 5 & 15.1 \\
\hline $2001-2003$ & 62 & 18 & 27.7 & 11 & 33.3 \\
\hline 2004-2006 & 58 & 15 & 23.1 & 8 & 24.2 \\
\hline $2007-2009$ & 77 & 20 & 30.8 & 9 & 27.3 \\
\hline Total & 254 & 65 & 100.0 & 33 & 100.0 \\
\hline
\end{tabular}


Table 2. Variable definitions

Panel A. Dependent variables

Tobin’s Q

3-year BHAR

3-year ROA

M\&A target

University Affiliation

VC Backing

PRESTIGE-UNI
Ratio of market value of assets, calculated as the sum of the book value of assets and the market value of common stock less (calculated at offer prices) the book value of common stock, over book value of assets. Source: EURIPO.

3-year Buy-and-Hold Abnormal Returns calculates as in Loughran and Ritter (1995). Source: EURIPO and Datastream.

3-year-average Return on Asset (ROA), calculated by using the ratio between EBIT (Earnings Before Interest and Taxation) and Total Assets, in the three years following the IPO. Source: EURIPO.

Dummy variable equal to 1 if the firm has been the target of an M\&A deal within 5 years (Meoli et al., 2013). Source: Thomson One Banker Deals.

\section{Panel B. Explanatory variables}

Dummy variable, equal to 1 for firms affiliated with a university, 0 otherwise. Universityaffiliated firms are identified as companies that were either developed by faculty members based on their own research or created specifically to capitalize on academic research. This information comes from IPO prospectuses, which are required to describe the full history of the firm and include the curricula vitae of its founder(s) and current upper echelons. An example of text identifying university affiliation follows. "The Company was formed in 1996 at Brunel University Science Park, Uxbridge, to research and develop a number of technologies [...] and to make use of Dr. [name omitted]'s experience"

Dummy variable, equal to 1 for firms backed by VCs at the time of the IPO, 0 otherwise. Venture capital firms are identified as in Vismara et al. (2012) among firms with institutional shareholders that focus on start-up financing. This information comes from a detailed examination of the directors' associations and 'Other significant shareholders' section of the IPO prospectuses. Such information is provided for at least three years prior to the IPO. In order to identify VC firms, several sources were used: the national associations such as the European Private Equity and Venture Capital Association (EVCA), the British Venture Capital Association (BVCA), the Association Francaise des Investisseurs en Capital (AFIC), the Bundesverband Deutscher Kapitalbeteiligungsgesellschaften (BVK), the Associazione italiana del private equity e venture capital (AIFI), and the National Venture Capital Association (NVCA). We also used other directories, including Pratt's Guide to VC Sources and the VC Resource Directory. Finally, we also included VC Trusts managed by established VC firms.

The prestige of universities is measured as the total number of citations (in thousands) received by all papers ("articles") published by the parent university in the twenty years before the IPO year in the following disciplines: Medicine; Biochemistry and Genetics; Nursing; Dentistry; Chemistry; Pharmacology, Toxicology and Pharmaceutics; Agriculture and Biological Sciences; Neuroscience; Immunology and Microbiology; Veterinary; Health professions; Chemical engineering. Following Gittelman and Kogut (2003), in regression analysis, raw citations are normalized by the mean and standard deviation of citations received by all sampled articles that were published in a given year. Normalizing the raw citations by year allows citations to be summed across years for each university. Source: Scopus. 
PRESTIGE-SC

PRESTIGE-VC

PRESTIGE-UW

Age (years)

Profitability (\%)

Leverage (\%)

Dilution ratio

Participation ratio

Prone to IPO (IMR)

Patents

UE size (No.)

UE with $\mathrm{PhD}$

UE with MBA

UE business experience
The scientific prestige is measured as the total number of citations (in thousands) received by all papers ("articles") published by members of the upper echelon of a certain IPO firm in the twenty years before the IPO year in the following disciplines: Medicine; Biochemistry and Genetics; Nursing; Dentistry; Chemistry; Pharmacology, Toxicology and Pharmaceutics; Agriculture and Biological Sciences; Neuroscience; Immunology and Microbiology; Veterinary; Health professions; Chemical engineering. Following Gittelman and Kogut (2003), in regression analysis, raw citations are normalized by the mean and standard deviation of citations received by all sampled articles that were published in a given year. Normalizing the raw citations by year allows citations to be summed across years for each firm. Source: Scopus.

The prestige of the VC supporting the IPO firm $i$ is measured, similarly to Nahata (2008), as the cumulative market capitalization of all IPOs in the sample backed by the same VC before the IPO of firm $i$.

The prestige of the UW supporting the IPO firm $i$ is measured as the capital raised by the UW taking public companies in the sample before $i$ went public, divided by the capital raised by all the IPOs in the sample, previous to the IPO of firm $i$. Only lead and co-lead underwriters are considered. When more than one underwriter underwrites an issue, the proceeds (and number of IPOs) are equally split among all lead banks, as in Aggarwal et al. (2002) and Abrahamson et al. (2011). Underwriters that have been acquired during the sampling period are treated as part of the new parent.

Panel C. Controls

Inflation-adjusted sales in the year prior to the IPO in 2008 millions of Euros, using Purchasing Power Parities (EU27=1). Yearly average exchange rates are used before 2009 between the ECU and national currencies to obtain a euro-equivalent and for companies based in non-euro countries. Source: EURIPO, Eurostat and Datastream. Natural logarithms are used in the regressions.

Years since incorporation at the time of the IPO. Source: EURIPO. Natural logarithms of $($ Age +1$)$ are used in the regressions.

Return on assets, in the year prior to the IPO. Source: EURIPO and Amadeus.

Ratio of debt to total assets, in the year prior to the IPO. Source: EURIPO and Amadeus.

Shares offered at listing over number of shares outstanding before the IPO. Source: EURIPO and Dealogic.

Percentage of the offer made of shares sold by existing shareholders. Source: EURIPO and Dealogic.

Inverse Mills Ratio, calculated as in Heckman (1979), correcting for the selection of firms that go public rather than remaining private, as described in the methodological section. Source: Amadeus, for all variables related to the matching sample of private firms.

Number of registered patents by the US and European Patent Offices issued to the firm up to the date of the IPO. Natural logarithms are used in the regressions. Source: EURIPO, EPO and USPTO.

Number of board members and top managers (upper echelons). Natural logarithms are used in the regressions. Source: EURIPO.

Proportion of upper echelons that hold a PhD degree. Source: EURIPO.

Proportion of upper echelons with an MBA degree. Source: EURIPO.

Proportion of upper echelons who had prior experience managing biotechnological or pharmaceutical companies. Source: EURIPO. 
Non executives (\%) Fraction of non-executive board directors. Source: EURIPO.

Corporate spinoff

Dummy variable for firms that are concentrated around activities that were originally developed in a parent firm (Clarysee et al. 2011). Source: EURIPO and IPO prospectuses.

Alliances

Number of alliances, joint ventures, licensing, R\&D collaborations, marketing/distribution, manufacturing and supply agreements (Guo et al., 2005). Natural logarithms are used in the regressions. Source: EURIPO and IPO prospectuses.

Country dummies

Set of dummy variables controlling for companies in UK, Germany, France and Italy. Reference case is company from other countries.

Set of dummy variables controlling for sub industry in the biotech sector: immunology,

Industry dummies diagnostics, investigation new drug, protein engineering, instruments and services. Reference case is services. See Meoli et al. (2013) for details. Source: IPO prospectuses. 
Table 3. Descriptive statistics

\begin{tabular}{lccc} 
& Mean & Std Dev & Median \\
\hline Depedent variables & & & \\
Tobin's Q & 3.94 & 2.99 & 2.94 \\
3-year BHAR (\%) & -30.15 & 103.72 & -55.50 \\
3-year ROA (\%) & -24.55 & 56.61 & -6.42 \\
M\&A target (\%) & 58.27 & 49.41 & 1 \\
Explanatory variables & & & \\
University Affiliation (\%) & 25.59 & 43.72 & 0 \\
VC Backing (\%) & 42.13 & 49.47 & 0 \\
PRESTIGE-SC & 2.76 & 7.07 & 0.42 \\
PRESTIGE-UNI & 204.71 & 225.93 & 184.34 \\
PRESTIGE-VC & 0.36 & 0.29 & 0.24 \\
PRESTIGE-UW & 0.19 & 0.15 & 0.15 \\
Controls & & & \\
Firm size (Sales, $€ m)$ & 40.29 & 135.13 & 4.38 \\
Age (years) & 9.53 & 11.76 & 7 \\
Profitability (\%) & -51.21 & 226.32 & -11.11 \\
Leverage (\%) & 75.85 & 70.68 & 44.96 \\
Dilution ratio (\%) & 51.85 & 83.22 & 39.5 \\
Participation ratio (\%) & 15.45 & 27.03 & 22.12 \\
Patents (No.) & 40.44 & 108.23 & 7 \\
UE Size & 9.43 & 4.45 & 9 \\
UE with Ph.D. (\%) & 23.25 & 22.63 & 20.00 \\
UE with MBA (\%) & 17.95 & 20.83 & 12.48 \\
UE business experience (\%) & 33.82 & 12.93 & 35.00 \\
Non executives (\%) & 28.39 & 19.46 & 28.57 \\
Corporate spinoff (\%) & 35.04 & 47.80 & 0 \\
Alliances (No.) & 1.04 & 0.11 & 1 \\
\hline Statistics on PRESTIGE-UNI and & PRESTIGE-VC are \\
calculated considering only & observations affiliated to a \\
University and supported by a VC, respectively. & \\
& & &
\end{tabular}


Table 4. Valuation at the IPO. Difference-in-difference estimation results

Difference-in-difference tests including control variables. Firms are assigned to the group with prestigious (non-prestigious) scientists if PRESTIGE-SC is above (below) the median value. Firms are assigned to the group with prestigious university (treated) if they are affiliated to a university and PRESTIGE-UNI is above the median value, or to the control group if they are non-affiliated or affiliated to university with PRESTIGE-UNI below the median value.

Tobin's Q Std Dev t-test

Non-prestigious scientists

Treated $(\mathrm{T})$ - Firms affiliated with prestigious universities

Control (C) - Firms affiliated with non-prestigious universities and non-affiliated firms

$\Delta 1(\mathrm{~T}-\mathrm{C})$

3.16

$1.092 .90^{* * * *}$

Prestigious scientists

Treated $(\mathrm{T})$ - Firms affiliated with prestigious universities 6.64

Control (C) - Firms affiliated with non-prestigious universities and non-affiliated firms

5.00

$\Delta 2(\mathrm{~T}-\mathrm{C})$

1.64

1.01

1.62

$\Delta=\Delta 1-\Delta 2$

1.52

$0.66 \quad 2.30 * *$


Table 5. Valuation at the IPO: OLS on the Tobin's Q

Models (1-5) are OLS regressions on valuation at the IPO measured through Tobin's Q. Model (1) is our baseline specification, including measures of University Prestige, PRESTIGE-UNI, Scientific Prestige, PRESTIGE-SC, Venture Capital Prestige, PRESTIGE-VC, and Underwriter Prestige, PRESTIGE-UW, as well as all control variables. Model (2) includes the interaction between PRESTIGE-UNI and PRESTIGE-SC. Model (3) includes the interaction between PRESTIGE-UNI and PRESTIGE-VC. Model (4) includes the interaction between PRESTIGEUNI and PRESTIGE-UW. Model (5) includes the three interactions. VC Affiliation are the residuals after regressing the variable against University affiliation, PRESTIGE-UNI, PRESTIGE-SC, country and year control variables; Prestige-VC are the residuals after regressing the variable against: University affiliation, PRESTIGE-UNI, PRESTIGE-SC, country and year control variables; Prestige- $U W$ are the residuals after regressing the variable against: University affiliation, PRESTIGE-UNI, PRESTIGE-SC, VC Backing, Prestige-VC, country and year control variables. All models include the Inverse Mills' Ratio (Prone to IPO - IMR) estimated in a first stage regression, where age, revenues, number of employees, time dummies, market and sub-industry dummies estimate the probability to go public (see Table A10). Robust standard errors in parentheses. $* * * * *$ and $*$ represent statistical significance at $0.01,0.05$ and 0.10 respectively. 


\begin{tabular}{|c|c|c|c|c|c|}
\hline & $(1)$ & $(2)$ & $(3)$ & $(4)$ & $(5)$ \\
\hline \multirow[t]{2}{*}{ Firm size } & $-0.260 * * *$ & $-0.258 * * *$ & $-0.254 * * *$ & $-0.262 * * *$ & $-0.254 * * *$ \\
\hline & $(0.057)$ & $(0.056)$ & $(0.057)$ & $(0.058)$ & $(0.057)$ \\
\hline \multirow[t]{2}{*}{ Age } & -0.003 & -0.061 & -0.025 & 0.000 & -0.082 \\
\hline & $(0.544)$ & $(0.535)$ & $(0.543)$ & $(0.545)$ & $(0.535)$ \\
\hline \multirow{2}{*}{ Profitability } & $0.316^{* *}$ & $0.336 * *$ & $0.324 * *$ & $0.316^{* *}$ & $0.346^{* *}$ \\
\hline & $(0.146)$ & $(0.144)$ & $(0.146)$ & $(0.146)$ & $(0.143)$ \\
\hline \multirow[t]{2}{*}{ Leverage } & $0.459 * * *$ & $0.450 * * *$ & $0.465 * * *$ & $0.458 * * *$ & $0.457 * * *$ \\
\hline & (0.119) & (0.117) & (0.119) & (0.119) & (0.117) \\
\hline \multirow[t]{2}{*}{ Dilution ratio } & 0.217 & 0.201 & 0.210 & 0.229 & 0.211 \\
\hline & $(0.330)$ & $(0.324)$ & $(0.329)$ & $(0.332)$ & $(0.326)$ \\
\hline \multirow[t]{2}{*}{ Participation ratio } & 1.081 & 1.098 & 1.111 & 1.069 & 1.113 \\
\hline & $(1.182)$ & $(1.162)$ & $(1.180)$ & $(1.185)$ & $(1.161)$ \\
\hline \multirow[t]{2}{*}{ Patents } & -0.018 & -0.085 & -0.017 & -0.015 & -0.082 \\
\hline & $(0.153)$ & $(0.152)$ & $(0.153)$ & $(0.154)$ & $(0.152)$ \\
\hline \multirow[t]{2}{*}{ UE size } & 0.003 & 0.008 & 0.029 & 0.008 & 0.043 \\
\hline & $(0.579)$ & $(0.570)$ & $(0.578)$ & $(0.581)$ & $(0.569)$ \\
\hline \multirow[t]{2}{*}{ UE with Ph.D. } & -1.720 & -1.596 & -1.807 & -1.711 & -1.675 \\
\hline & $(1.461)$ & $(1.437)$ & (1.459) & (1.464) & $(1.436)$ \\
\hline \multirow[t]{2}{*}{ UE with MBA } & -2.211 & -2.060 & -2.264 & -2.211 & -2.114 \\
\hline & $(1.445)$ & $(1.422)$ & $(1.442)$ & $(1.448)$ & $(1.420)$ \\
\hline \multirow{2}{*}{ UE business experience } & -0.227 & -0.143 & -0.109 & -0.143 & 0.117 \\
\hline & $(2.593)$ & $(2.549)$ & (2.589) & $(2.611)$ & $(2.559)$ \\
\hline \multirow[t]{2}{*}{ Non executives } & $-2.418 *$ & $-2.520 *$ & -2.237 & $-2.430 *$ & $-2.342^{*}$ \\
\hline & $(1.411)$ & $(1.388)$ & $(1.414)$ & $(1.414)$ & $(1.392)$ \\
\hline \multirow[t]{2}{*}{ Corporate spinoff } & 0.213 & 0.205 & 0.212 & 0.229 & 0.227 \\
\hline & $(0.638)$ & $(0.628)$ & $(0.637)$ & $(0.642)$ & $(0.629)$ \\
\hline \multirow[t]{2}{*}{ Alliances } & 5.490 & 5.285 & 5.553 & 5.346 & 5.133 \\
\hline & $(4.236)$ & $(4.182)$ & $(4.229)$ & $(3.272)$ & $(3.208)$ \\
\hline \multirow[t]{2}{*}{ University Affiliation } & -1.765 & -1.164 & $-1.805^{*}$ & -1.779 & -1.206 \\
\hline & $(1.075)$ & (1.076) & $(1.073)$ & $(1.078)$ & $(1.074)$ \\
\hline \multirow[t]{2}{*}{ VC Backing } & -0.542 & -0.511 & -0.466 & -0.580 & -0.483 \\
\hline & $(0.718)$ & $(0.706)$ & $(0.718)$ & $(0.729)$ & $(0.716)$ \\
\hline \multirow[t]{2}{*}{ Prone to IPO (IMR) } & -0.839 & -0.888 & -1.051 & -0.840 & -1.126 \\
\hline & (3.203) & (3.149) & (3.200) & (3.209) & $(3.148)$ \\
\hline \multirow[t]{2}{*}{ PRESTIGE-UNI } & $0.360 * * *$ & $0.370 * * *$ & $0.358 * * *$ & $0.361 * * *$ & $0.370 * * *$ \\
\hline & $(0.103)$ & $(0.101)$ & $(0.102)$ & $(0.103)$ & $(0.101)$ \\
\hline \multirow[t]{2}{*}{ PRESTIGE-SC } & $0.337 * * *$ & $0.370 * * *$ & $0.338 * * *$ & $0.336 * * *$ & $0.371 * * *$ \\
\hline & $(0.094)$ & $(0.093)$ & $(0.094)$ & $(0.094)$ & $(0.093)$ \\
\hline \multirow[t]{2}{*}{ PRESTIGE-VC } & $3.400 * * *$ & $3.257 * * *$ & $3.072 * *$ & $3.444 * * *$ & $2.955^{* *}$ \\
\hline & $(1.259)$ & $(1.239)$ & $(1.278)$ & $(1.269)$ & $(1.266)$ \\
\hline PRESTIGE-UW & $4.546 * * *$ & $5.139 * * *$ & $4.477 * * *$ & $4.342 * *$ & $4.781 * * *$ \\
\hline & $(1.670)$ & $(1.654)$ & $(1.668)$ & $(1.789)$ & $(1.760)$ \\
\hline PRESTIGE-UNI x PRESTIGE-SC & - & $\begin{array}{c}-0.062 * * * \\
(0.021)\end{array}$ & - & - & $\begin{array}{c}-0.065 * * * \\
(0.021)\end{array}$ \\
\hline PRESTIGE-UNI x PRESTIGE-VC & - & - & -0.365 & - & -0.403 \\
\hline & & & $(0.260)$ & & $(0.256)$ \\
\hline PRESTIGE-UNI x PRESTIGE-UW & - & - & - & 0.094 & 0.141 \\
\hline & & & & $(0.293)$ & $(0.288)$ \\
\hline Constant & $10.445^{* * *}$ & $10.762 * * *$ & $10.383 * * *$ & $10.421 * * *$ & $10.671 * * *$ \\
\hline & (3.191) & (3.139) & (3.184) & (3.198) & $(3.135)$ \\
\hline Observations & 254 & 254 & 254 & 254 & 254 \\
\hline R-squared & 0.428 & 0.457 & 0.429 & 0.428 & 0.460 \\
\hline Adjusted R-squared & 0.307 & 0.339 & 0.305 & 0.304 & 0.336 \\
\hline
\end{tabular}




\section{Table 6. Long-run analysis}

Models (1-4) are OLS regressions on post-IPO performances, measured through 3-year BHAR (Models 1-2) and 3-year average ROA (Model 3-4). Models (5-6) are probit regressions on the probability for a firm to be the target of an M\&A in the five years post the IPO (Model 5-6). VC Affiliation are the residuals after regressing the variable against University affiliation, PRESTIGE-UNI, PRESTIGE-SC, country and year control variables; Prestige-VC are the residuals after regressing the variable against: University affiliation, PRESTIGE-UNI, PRESTIGE-SC, country and year control variables; Prestige-UW are the residuals after regressing the variable against: University affiliation, PRESTIGE-UNI, PRESTIGE-SC, VC Backing, Prestige-VC, country and year control variables. All models include the Inverse Mills' Ratio (Prone to IPO - IMR) estimated in a first stage regression, where age, revenues, number of employees, time dummies, market and sub-industry dummies estimate the probability to go public (see Table A10). Controls for years, markets and sub-industries are included. Robust standard errors in parentheses. $* * * * *$ and $*$ represent statistical significance at $0.01,0.05$ and 0.10 respectively. 
(1)

(2)

(3)

(4)

(5)

(6)

3Y-BHAR

$3 \mathrm{Y}-\mathrm{BHAR}$

3Y-ROA

3Y-ROA

M\&A target M\&A target

\begin{tabular}{|c|c|c|c|c|c|c|}
\hline Firm size & $\begin{array}{c}0.002 \\
(0.013)\end{array}$ & $\begin{array}{c}0.000 \\
(0.013)\end{array}$ & $\begin{array}{c}0.001 \\
(0.008)\end{array}$ & $\begin{array}{c}0.004 \\
(0.008)\end{array}$ & $\begin{array}{l}0.035^{*} \\
(0.019)\end{array}$ & $\begin{array}{l}0.037 * \\
(0.019)\end{array}$ \\
\hline \multirow[t]{2}{*}{ Age } & 0.016 & 0.018 & 0.179 & 0.159 & -0.115 & -0.153 \\
\hline & $(0.136)$ & $(0.128)$ & $(0.149)$ & $(0.147)$ & $(0.187)$ & $(0.190)$ \\
\hline \multirow[t]{2}{*}{ Profitability } & -0.037 & $-0.071 * *$ & 0.001 & 0.004 & -0.023 & -0.019 \\
\hline & $(0.028)$ & $(0.034)$ & $(0.017)$ & $(0.017)$ & $(0.055)$ & $(0.059)$ \\
\hline \multirow[t]{2}{*}{ Leverage } & -0.027 & -0.059 & $-0.042 * * *$ & $-0.040 * * *$ & -0.052 & -0.057 \\
\hline & $(0.031)$ & $(0.038)$ & $(0.013)$ & $(0.013)$ & $(0.041)$ & $(0.044)$ \\
\hline \multirow[t]{2}{*}{ Dilution ratio } & -0.077 & -0.142 & 0.023 & 0.023 & -0.116 & -0.114 \\
\hline & $(0.113)$ & $(0.126)$ & $(0.026)$ & $(0.026)$ & $(0.112)$ & $(0.106)$ \\
\hline \multirow[t]{2}{*}{ Participation ratio } & 0.021 & 0.211 & -0.057 & -0.042 & 0.511 & 0.521 \\
\hline & $(0.226)$ & $(0.221)$ & $(0.103)$ & $(0.098)$ & $(0.374)$ & $(0.378)$ \\
\hline \multirow[t]{2}{*}{ Patents } & 0.005 & 0.032 & $0.036^{*}$ & 0.027 & $0.131 * * *$ & $0.111 * *$ \\
\hline & $(0.037)$ & $(0.035)$ & $(0.020)$ & $(0.019)$ & $(0.050)$ & $(0.050)$ \\
\hline \multirow{2}{*}{ UE size } & 0.054 & 0.103 & -0.061 & -0.056 & -0.080 & -0.083 \\
\hline & $(0.137)$ & $(0.135)$ & $(0.058)$ & $(0.058)$ & $(0.188)$ & $(0.189)$ \\
\hline \multirow{2}{*}{ UE with Ph.D. } & -0.207 & 0.136 & 0.237 & 0.248 & 0.717 & $0.782 *$ \\
\hline & $(0.275)$ & $(0.271)$ & $(0.219)$ & $(0.213)$ & $(0.437)$ & $(0.442)$ \\
\hline \multirow{2}{*}{ UE with MBA } & -0.098 & -0.083 & -0.065 & -0.046 & -0.195 & -0.117 \\
\hline & $(0.289)$ & $(0.279)$ & $(0.193)$ & $(0.189)$ & $(0.455)$ & $(0.464)$ \\
\hline \multirow[t]{2}{*}{ UE business experience } & -0.021 & -0.110 & -0.069 & -0.070 & -1.171 & -1.158 \\
\hline & $(0.643)$ & $(0.620)$ & $(0.254)$ & $(0.242)$ & $(0.864)$ & $(0.874)$ \\
\hline \multirow[t]{2}{*}{ Non-Executive Directors } & $-0.880 *$ & $-0.980 * *$ & 0.184 & 0.199 & 0.594 & 0.566 \\
\hline & $(0.490)$ & $(0.484)$ & $(0.204)$ & $(0.204)$ & $(0.481)$ & $(0.486)$ \\
\hline \multirow[t]{2}{*}{ Corporate spinoff } & 0.137 & 0.098 & 0.043 & 0.033 & -0.007 & -0.029 \\
\hline & $(0.188)$ & $(0.187)$ & $(0.065)$ & $(0.065)$ & $(0.212)$ & $(0.214)$ \\
\hline \multirow[t]{2}{*}{ Alliances } & 3.670 & 4.070 & 0.788 & 0.730 & 0.868 & 0.748 \\
\hline & $(2.519)$ & $(3.309)$ & $(0.755)$ & $(0.722)$ & $(1.015)$ & $(1.051)$ \\
\hline \multirow[t]{2}{*}{ University Affiliation } & $-0.870^{*}$ & $-0.722 *$ & -0.278 & -0.186 & $-0.555^{*}$ & -0.340 \\
\hline & $(0.455)$ & $(0.420)$ & $(0.182)$ & $(0.171)$ & $(0.284)$ & $(0.296)$ \\
\hline \multirow[t]{2}{*}{ VC Backing } & $-0.292 *$ & -0.251 & -0.078 & -0.065 & -0.342 & -0.324 \\
\hline & $(0.162)$ & $(0.159)$ & $(0.072)$ & $(0.071)$ & $(0.223)$ & $(0.221)$ \\
\hline \multirow[t]{2}{*}{ Prone to IPO (IMR) } & -0.226 & 0.048 & 0.718 & 0.677 & -0.928 & -1.003 \\
\hline & $(0.777)$ & $(0.718)$ & $(0.571)$ & $(0.570)$ & $(1.132)$ & (1.138) \\
\hline \multirow[t]{2}{*}{ PRESTIGE-UNI } & $0.090 * *$ & $0.077 * *$ & $0.030 *$ & $0.028 *$ & $0.053 * *$ & $0.057 * *$ \\
\hline & $(0.035)$ & $(0.033)$ & $(0.017)$ & $(0.017)$ & $(0.024)$ & $(0.024)$ \\
\hline \multirow[t]{2}{*}{ PRESTIGE-SC } & $0.018 * *$ & $0.021 * *$ & $0.021 * *$ & $0.022 * * *$ & $0.056^{*}$ & $0.067 * *$ \\
\hline & $(0.009)$ & $(0.009)$ & $(0.009)$ & $(0.009)$ & $(0.029)$ & $(0.030)$ \\
\hline \multirow[t]{2}{*}{ PRESTIGE-VC } & $0.745 * * *$ & $0.776^{* * *}$ & $0.211 * *$ & $0.208 * *$ & $0.994 * * *$ & $0.948 * *$ \\
\hline & $(0.268)$ & $(0.256)$ & $(0.086)$ & $(0.094)$ & $(0.374)$ & $(0.372)$ \\
\hline \multirow[t]{2}{*}{ PRESTIGE-UW } & $0.236^{* *}$ & $0.265^{* * *}$ & $1.130^{*}$ & 1.081 & $0.829 * *$ & $0.983^{* * *}$ \\
\hline & $(0.118)$ & $(0.080)$ & $(0.677)$ & $(0.747)$ & $(0.389)$ & $(0.367)$ \\
\hline PRESTIGE-UNI x PRESTIGE-SC & - & $-0.080 * * *$ & - & $-0.007 *$ & - & $-0.021 * * *$ \\
\hline & & $(0.025)$ & & $(0.004)$ & & $(0.008)$ \\
\hline PRESTIGE-UNI x PRESTIGE-VC & - & 0.367 & - & 2.350 & - & 2.965 \\
\hline & & $(4.526)$ & & $(1.683)$ & & $(6.653)$ \\
\hline PRESTIGE-UNI x PRESTIGE-UW & - & -0.669 & - & -0.034 & - & 0.931 \\
\hline & & $(0.570)$ & & $(0.040)$ & & $(1.485)$ \\
\hline Constant & 0.177 & -0.323 & -0.893 & -0.884 & 0.208 & 0.339 \\
\hline & $(0.842)$ & $(0.772)$ & $(0.634)$ & $(0.631)$ & $(1.104)$ & $(1.115)$ \\
\hline Observations & 254 & 254 & 254 & 254 & 254 & 354 \\
\hline (Pseudo) R-squared & 0.589 & 0.620 & 0.255 & 0.273 & $(0.253)$ & $(0.266)$ \\
\hline Adjusted R-squared & 0.459 & 0.488 & 0.0982 & 0.107 & - & - \\
\hline
\end{tabular}


Table 7. Natural experiment: Pre and post EU-Sox evidence

This table reports our tests for interactions between "exchange-regulated markets" and "post-EuropeanSox-like provisions" dummies with the four measures of prestige considered in the paper. The dependent variable is ToBin's Q at the IPO. The interaction of the Eu-Sox on regulated markets with each signal is analyzed in a separate column: in Model (1) with PRESTIGE-UNI, in Model (2) with PRESTIGE-SC, in Model (3) with PRESTIGE-VC, in Model (4) with PRESTIGE-UW. In Models (5-7) all signals are interacted together with Eu-Sox on regulated markets: Model (5) refers to the full sample, Model (6) is estimated on the sub-sample of firms with PRESTIGE-SC below the median value, Model (7) is estimated on the sub-sample of firms with PRESTIGE-SC above the median value. VC Affiliation are the residuals after regressing the variable against University affiliation, PRESTIGE-UNI, country and year control variables; Prestige-VC are the residuals after regressing the variable against: University affiliation, PRESTIGE-UNI, country and year control variables; Prestige-UW are the residuals after regressing the variable against: University affiliation, PRESTIGE-UNI, VC Backing, Prestige-VC, country and year control variables. All models include the Inverse Mills' Ratio (Prone to IPO - IMR) estimated in a first stage regression, where age, revenues, number of employees, time dummies, market and sub-industry dummies estimate the probability to go public (see Table A10). Controls for years, markets and sub-industries are included. Robust standard errors in parentheses. ***, ** and * represent statistical significance at $0.01,0.05$ and 0.10 respectively. 


\begin{tabular}{|c|c|c|c|c|c|c|c|}
\hline & $(1)$ & (2) & (3) & (4) & $(5)$ & $(6)$ & (7) \\
\hline \multirow[t]{2}{*}{ Firm size } & $-0.263 * * *$ & $-0.260 * * *$ & $-0.269 * * *$ & $-0.249 * * *$ & $-0.252 * * *$ & $-0.154 *$ & $-0.210 * * *$ \\
\hline & $(0.058)$ & $(0.057)$ & $(0.057)$ & $(0.057)$ & $(0.057)$ & $(0.082)$ & $(0.076)$ \\
\hline \multirow[t]{2}{*}{ Age } & -0.001 & -0.083 & -0.021 & 0.156 & 0.029 & -0.170 & 0.443 \\
\hline & $(0.547)$ & $(0.549)$ & $(0.538)$ & $(0.546)$ & $(0.541)$ & $(0.571)$ & $(0.997)$ \\
\hline \multirow[t]{2}{*}{ Profitability } & $0.316 * *$ & $0.296 * *$ & $0.307 * *$ & $0.297 * *$ & $0.257^{*}$ & -0.189 & 0.357 \\
\hline & $(0.147)$ & $(0.148)$ & $(0.145)$ & $(0.146)$ & $(0.145)$ & $(0.460)$ & $(0.298)$ \\
\hline \multirow[t]{2}{*}{ Leverage } & $0.453 * * *$ & $0.428 * * *$ & $0.447 * * *$ & $0.438 * * *$ & $0.399 * * *$ & $0.297 * *$ & 0.443 \\
\hline & $(0.120)$ & $(0.121)$ & $(0.118)$ & $(0.118)$ & $(0.119)$ & $(0.122)$ & $(0.317)$ \\
\hline \multirow[t]{2}{*}{ Dilution ratio } & 0.192 & 0.140 & 0.093 & 0.141 & -0.023 & 0.071 & -1.016 \\
\hline & $(0.332)$ & $(0.333)$ & $(0.328)$ & $(0.328)$ & $(0.329)$ & $(0.277)$ & $(1.380)$ \\
\hline \multirow[t]{2}{*}{ Participation ratio } & 0.919 & 0.835 & 1.057 & 1.289 & 1.313 & 0.131 & 3.033 \\
\hline & (1.193) & (1.191) & (1.174) & (1.192) & (1.177) & (1.036) & (3.234) \\
\hline \multirow[t]{2}{*}{ Patents } & -0.019 & -0.020 & -0.049 & 0.013 & -0.017 & -0.177 & 0.162 \\
\hline & $(0.154)$ & $(0.153)$ & $(0.152)$ & $(0.153)$ & $(0.151)$ & $(0.164)$ & $(0.247)$ \\
\hline \multirow[t]{2}{*}{ UE size } & -0.019 & -0.012 & 0.019 & -0.120 & -0.075 & 0.564 & -1.750 \\
\hline & $(0.582)$ & $(0.580)$ & $(0.573)$ & $(0.578)$ & $(0.570)$ & $(0.585)$ & $(1.054)$ \\
\hline \multirow[t]{2}{*}{ UE with $\mathrm{PhD}$} & -1.855 & -1.889 & -1.624 & -1.432 & -1.271 & -2.445 & 0.369 \\
\hline & $(1.470)$ & $(1.465)$ & $(1.448)$ & $(1.466)$ & $(1.450)$ & (1.919) & (2.078) \\
\hline \multirow[t]{2}{*}{ UE with MBA } & -2.212 & -2.377 & -1.895 & -2.300 & -2.217 & 1.023 & -2.944 \\
\hline & $(1.450)$ & $(1.452)$ & $(1.431)$ & $(1.435)$ & $(1.427)$ & (1.736) & (2.238) \\
\hline \multirow{2}{*}{ UE business exp. } & -0.040 & 0.111 & -0.427 & -0.729 & -0.861 & 0.071 & -3.072 \\
\hline & $(2.607)$ & $(2.601)$ & $(2.566)$ & $(2.595)$ & $(2.570)$ & $(2.375)$ & $(5.136)$ \\
\hline \multirow[t]{2}{*}{ Non-Executive Directors } & $-2.443 *$ & -2.308 & $-2.359 *$ & -1.825 & -1.564 & -2.105 & 0.163 \\
\hline & $(1.416)$ & $(1.416)$ & $(1.393)$ & $(1.428)$ & $(1.416)$ & $(1.487)$ & (2.479) \\
\hline \multirow[t]{2}{*}{ Corporate spinoff } & 0.173 & 0.202 & 0.277 & 0.456 & 0.598 & -0.440 & 0.852 \\
\hline & $(0.641)$ & $(0.640)$ & $(0.632)$ & $(0.647)$ & $(0.640)$ & $(0.657)$ & $(1.082)$ \\
\hline \multirow[t]{2}{*}{ Alliances } & 5.273 & 4.929 & 5.036 & $5.544 *$ & 4.846 & $5.910^{*}$ & 3.068 \\
\hline & $(3.250)$ & $(3.252)$ & (3.198) & $(3.217)$ & $(3.186)$ & $(3.251)$ & $(4.963)$ \\
\hline \multirow[t]{2}{*}{ Exchange-Regulated Markets } & -0.648 & -0.694 & -0.586 & -0.701 & -0.690 & -0.703 & -1.316 \\
\hline & $(0.549)$ & $(0.546)$ & $(0.539)$ & $(0.542)$ & $(0.537)$ & $(0.700)$ & $(1.180)$ \\
\hline Post EU Sox-like Provisions & 0.429 & 0.438 & 0.386 & 0.496 & 0.457 & $1.322 *$ & 0.175 \\
\hline & $(0.541)$ & $(0.538)$ & $(0.531)$ & $(0.535)$ & $(0.529)$ & $(0.746)$ & $(1.203)$ \\
\hline University Affiliation & $-1.784 *$ & -1.722 & -1.706 & -1.668 & -1.490 & -0.470 & $-2.979 *$ \\
\hline & $(1.079)$ & (1.076) & $(1.061)$ & $(1.068)$ & $(1.058)$ & $(1.083)$ & $(1.577)$ \\
\hline VC Backing & -0.498 & -0.498 & -0.244 & -0.669 & -0.394 & 0.469 & -0.779 \\
\hline & $(0.726)$ & $(0.718)$ & $(0.715)$ & $(0.716)$ & $(0.720)$ & $(0.787)$ & (1.042) \\
\hline Prone to IPO (IMR) & -0.859 & -1.285 & -1.894 & -0.212 & -1.786 & -0.409 & -6.914 \\
\hline & (3.214) & (3.222) & (3.182) & $(3.192)$ & (3.190) & (2.951) & $(7.436)$ \\
\hline PRESTIGE-UNI & $0.351 * * *$ & $0.359 * * *$ & $0.340 * * *$ & $0.353 * * *$ & $0.340 * * *$ & $0.369 * * *$ & $0.250 * *$ \\
\hline & $(0.114)$ & $(0.103)$ & $(0.101)$ & $(0.102)$ & $(0.112)$ & $(0.105)$ & $(0.098)$ \\
\hline PRESTIGE-SC & $0.340 * * *$ & $0.395 * * *$ & $0.318 * * *$ & $0.315 * * *$ & $0.367 * * *$ & 0.124 & $0.867 * * *$ \\
\hline & $(0.095)$ & $(0.105)$ & $(0.094)$ & $(0.094)$ & $(0.103)$ & $(0.143)$ & $(0.312)$ \\
\hline PRESTIGE-VC & $3.445 * * *$ & $3.420 * * *$ & $3.586 * * *$ & $3.400 * * *$ & $3.487 * * *$ & $2.825 * *$ & $4.342 * *$ \\
\hline & $(1.264)$ & $(1.260)$ & $(1.244)$ & $(1.250)$ & $(1.236)$ & $(1.217)$ & $(1.803)$ \\
\hline PRESTIGE-UW & $4.384 * *$ & $4.004 * *$ & $4.055 * *$ & $4.764 * * *$ & $3.969 * *$ & $3.443 * *$ & $3.497 *$ \\
\hline & (1.695) & (1.704) & $(1.658)$ & $(1.673)$ & (1.684) & $(1.460)$ & (1.935) \\
\hline PRESTIGE UNI $\times$ Post EU Sox $\times$ Reg & 0.013 & - & - & - & 0.006 & -0.113 & -0.101 \\
\hline & $(0.128)$ & & & & $(0.135)$ & $(0.207)$ & $(0.182)$ \\
\hline PRESTIGE-SC $\times$ Post EU Sox $\times$ Reg & - & -0.200 & - & - & -0.282 & 0.093 & -0.370 \\
\hline & & $(0.171)$ & & & $(0.179)$ & $(0.249)$ & $(0.465)$ \\
\hline PRESTIGE-VC $\times$ Post EU Sox $\times$ Reg & - & - & $-1.647 * * *$ & - & $-1.598 * * *$ & $-0.949 *$ & $-2.529 * *$ \\
\hline & & & $(0.599)$ & & $(0.601)$ & $(0.540)$ & $(1.063)$ \\
\hline PRESTIGE-UW $\times$ Post EU Sox $\times$ Reg & - & - & - & $-3.066 * *$ & $-3.051 * *$ & $-2.829 *$ & $-2.892 *$ \\
\hline & & & & $(1.384)$ & $(1.386)$ & $(1.541)$ & $(1.462)$ \\
\hline Constant & $10.715 * * *$ & $11.130 * * *$ & $11.239 * * *$ & $9.521 * * *$ & $10.566 * * *$ & $7.283 * *$ & $12.969 *$ \\
\hline & $(3.222)$ & (3.224) & (3.170) & $(3.229)$ & $(3.205)$ & $(2.909)$ & $(7.428)$ \\
\hline Observations & 254 & 254 & 254 & 254 & 254 & 127 & 127 \\
\hline R-squared & 0.429 & 0.432 & 0.456 & 0.441 & 0.470 & 0.703 & 0.642 \\
\hline Adjusted R-squared & 0.299 & 0.302 & 0.332 & 0.313 & 0.339 & 0.508 & 0.406 \\
\hline
\end{tabular}


Appendix

Table A1. Top European Universities, ranked according to the number of citations in the 20 years previous the IPO of an affiliated firm (universities are not repeated)

\begin{tabular}{cllc} 
Rank & & \multicolumn{1}{c}{ University } & Nountry \\
\hline 1 & University of Cambridge & United Kingdom & 4 \\
2 & Karolinska Institute & Sweden & 1 \\
3 & University of Oxford & United Kingdom & 7 \\
4 & University of Edinburgh & United Kingdom & 1 \\
5 & University of Amsterdam & The Netherlands & 1 \\
6 & Munich Technical University & Germany & 2 \\
7 & University of Oslo & Norway & 1 \\
8 & University of Manchester & United Kingdom & 3 \\
9 & University of Leeds & United Kingdom & 1 \\
10 & Newcastle University & United Kingdom & 1 \\
11 & University of Sheffield & United Kingdom & 1 \\
12 & Imperial College London & United Kingdom & 1 \\
13 & University of Erlangen-Norimberga & Germany & 2 \\
14 & University College of London & United Kingdom & 1 \\
15 & Swiss Federal Institute of Technology Zurich & Switzerland & 1 \\
16 & Ecole Polytechnique & France & 1 \\
17 & Ecole Normale Superieure, Paris & France & 1 \\
18 & University of Göttingen & Germany & 1 \\
19 & École Polytechnique Federale de Lausanne & Switzerland & 1 \\
20 & University of Munich & Germany & 2 \\
\hline
\end{tabular}


Table A2. Top Venture Capitalists, ranked by the number of venture-backed IPOs in the sample

\begin{tabular}{clcc} 
Rank & & Country & No. IPOs affiliated \\
\hline 1 & 3i plc & United Kingdom & 36 \\
2 & Atlas Venture Fund & United States & 12 \\
3 & Sofinova Capital II FCPR & United States & 10 \\
4 & Abingworth Bioventures II & United Kingdom & 8 \\
5 & TVM V Life Science Ventures GmbH \& Co. KG & Germany & 7 \\
6 & Invesco perpetual & United Kingdom & 6 \\
7 & Merlin Ventures Limited & United Kingdom & 6 \\
8 & Apax group & China & 5 \\
9 & HealthCap Companies & Sweden & 5 \\
10 & Life Science Partners & The Netherlands & 5 \\
11 & Schroeder Funds & Luxembourg & 5 \\
12 & Advent Venture Capital & United Kingdom & 4 \\
13 & AlpInvest Partners & The Netherlands & 4 \\
14 & Auriga Ventures & France & 4 \\
15 & Euroventures & Hungary & 4 \\
16 & GIMV & Belgium & 4 \\
17 & Index Ventures & United Kingdom & 4 \\
18 & KBC Private Equity & Belgium & 4 \\
19 & ABN Ambro & The Netherlands & 3 \\
20 & Alta Partners & United States & 3 \\
\hline
\end{tabular}


Table A3. Top Underwriters, ranked by the share of proceeds raised taking public the IPOs in the sample

\begin{tabular}{clcc} 
Investment bank & Country & No. IPOs affiliated \\
\hline 1 & Morgan Stanley \& Co. International & United States & 5 \\
2 & Commerzbank & Germany & 3 \\
3 & Goldman Sachs International & United States & 5 \\
4 & Citigroup & United States & 1 \\
5 & Intesa Sanpaolo & Italy & 2 \\
6 & UBS & Switzerland & 6 \\
7 & Noryt Company Establishment & Poland & 1 \\
8 & Mediobanca & Italy & 1 \\
9 & WestLB & Germany & 8 \\
10 & Nomura Code Securities Ltd & Japan & 4 \\
11 & Credit Suisse Securities & Switzerland & 3 \\
12 & Collins Stewart & United Kingdom & 9 \\
13 & HSBC Trinkaus & United Kingdom & 2 \\
14 & Kleinwort Benson & United Kingdom & 3 \\
15 & Deutsche Bank & Germany & 3 \\
16 & Nomura International & Japan & 3 \\
17 & Merrill Lynch International & United States & 2 \\
18 & Bank Vontobel & Switzerland & 1 \\
19 & ABG Sundal Collier & Norway & 2 \\
20 & KBC Peel Hunt & United Kingdom & 9 \\
\hline
\end{tabular}


Table A4. Correlation matrix.

\begin{tabular}{|c|c|c|c|c|c|c|c|c|c|c|c|c|c|}
\hline & & 1 & 2 & 3 & 4 & & 6 & 7 & 8 & 9 & 10 & 11 & 12 \\
\hline 1 & Tobin's Q & 1.000 & & & & & & & & & & & \\
\hline 2 & 3-year BHAR & $-0.157 *$ & 1.000 & & & & & & & & & & \\
\hline 3 & 3-year ROA & $-0.123 *$ & $-0.134 *$ & 1.000 & & & & & & & & & \\
\hline 4 & M\&A target & 0.023 & $0.159^{*}$ & 0.009 & 1.000 & & & & & & & & \\
\hline 5 & Firm size & $-0.386^{*}$ & $0.145^{*}$ & 0.028 & 0.080 & 1.000 & & & & & & & \\
\hline 6 & Age & $-0.200 *$ & 0.092 & 0.096 & 0.050 & $0.370^{*}$ & 1.000 & & & & & & \\
\hline 7 & Profitability & -0.119 & $0.133^{*}$ & 0.117 & 0.055 & $0.231 *$ & $0.141 *$ & 1.000 & & & & & \\
\hline 8 & Leverage & $0.219^{*}$ & -0.104 & $-0.209^{*}$ & -0.067 & $-0.135^{*}$ & -0.111 & $-0.593^{*}$ & 1.000 & & & & \\
\hline 9 & Dilution ratio & 0.079 & 0.047 & 0.003 & -0.118 & $-0.122 *$ & -0.087 & 0.030 & -0.037 & 1.000 & & & \\
\hline 10 & Participation ratio & $0.203 *$ & -0.081 & -0.027 & 0.116 & $-0.314 *$ & $-0.256^{*}$ & $-0.122 *$ & 0.075 & $0.134 *$ & 1.000 & & \\
\hline 11 & Patents & -0.005 & 0.040 & 0.090 & 0.105 & 0.051 & -0.022 & 0.064 & -0.038 & -0.099 & 0.068 & 1.000 & \\
\hline 12 & UE size & -0.032 & $0.138^{*}$ & -0.004 & -0.071 & 0.099 & 0.045 & -0.032 & -0.005 & -0.090 & 0.016 & 0.097 & 1.000 \\
\hline 13 & UE with PhD & 0.111 & -0.015 & 0.109 & $0.250 *$ & $-0.261 *$ & $-0.126^{*}$ & $-0.127 *$ & 0.029 & -0.024 & $0.280 *$ & $0.162 *$ & $0.147 *$ \\
\hline 14 & UE with MBA & -0.043 & 0.061 & 0.069 & $0.195 *$ & -0.095 & -0.050 & 0.039 & -0.037 & 0.018 & $0.284 *$ & $0.159 *$ & $0.178^{*}$ \\
\hline 15 & UE business exp. & 0.068 & -0.109 & 0.011 & $0.173^{*}$ & $-0.156^{*}$ & $-0.173 *$ & -0.097 & 0.038 & 0.002 & $0.448 *$ & 0.082 & $-0.142 *$ \\
\hline 16 & Non-Executive Directors & -0.075 & -0.010 & 0.070 & 0.070 & -0.064 & 0.019 & -0.066 & 0.018 & -0.013 & 0.048 & -0.014 & $0.191 *$ \\
\hline 17 & Corporate Spinoff & -0.040 & 0.007 & 0.016 & -0.012 & 0.053 & $-0.138 *$ & -0.044 & 0.112 & -0.058 & 0.011 & 0.048 & $0.131 *$ \\
\hline 18 & Alliances & -0.052 & 0.038 & -0.057 & $0.129 *$ & 0.095 & 0.081 & 0.037 & -0.072 & -0.028 & -0.050 & $0.189^{*}$ & $0.127 *$ \\
\hline 19 & University Affiliation & $0.207 *$ & $0.140 *$ & -0.077 & -0.004 & $-0.178 *$ & $-0.123 *$ & -0.054 & -0.018 & -0.021 & $0.207 *$ & 0.027 & 0.005 \\
\hline 20 & VC Backing & 0.120 & 0.003 & 0.010 & $0.205^{*}$ & $-0.142 *$ & -0.020 & -0.056 & 0.055 & -0.029 & $0.155^{*}$ & $0.191^{*}$ & 0.092 \\
\hline 21 & PRESTIGE-SC & $0.305^{*}$ & -0.028 & -0.018 & -0.064 & $-0.265 *$ & $-0.171 *$ & $-0.172 *$ & 0.022 & $-0.131 *$ & $0.352 *$ & $0.205^{*}$ & $0.170^{*}$ \\
\hline 22 & PRESTIGE-UNI & $0.298^{*}$ & 0.087 & -0.095 & $0.156^{*}$ & $-0.200 *$ & $-0.200 *$ & -0.067 & 0.008 & -0.036 & $0.187^{*}$ & 0.018 & 0.056 \\
\hline 23 & PRESTIGE-VC & $0.168 *$ & 0.066 & 0.010 & -0.021 & -0.097 & 0.033 & -0.002 & -0.013 & 0.085 & -0.025 & 0.014 & -0.009 \\
\hline \multirow[t]{2}{*}{24} & PRESTIGE-UW & $0.124 *$ & -0.059 & -0.011 & $0.217 *$ & 0.070 & -0.021 & 0.013 & -0.043 & $0.151 *$ & -0.013 & 0.114 & $0.441 *$ \\
\hline & & 13 & 14 & 15 & 16 & 17 & 18 & 19 & 20 & 21 & 22 & 23 & 24 \\
\hline 13 & UE with $\mathrm{PhD}$ & 1.000 & & & & & & & & & & & \\
\hline 14 & UE with MBA & $0.306^{*}$ & 1.000 & & & & & & & & & & \\
\hline 15 & UE business exp. & $0.410^{*}$ & $0.374 *$ & 1.000 & & & & & & & & & \\
\hline 16 & Non-Executive Directors & -0.025 & $0.137 *$ & -0.008 & 1.000 & & & & & & & & \\
\hline 17 & Corporate Spinoff & -0.033 & 0.043 & 0.041 & -0.011 & 1.000 & & & & & & & \\
\hline 18 & Alliances & 0.004 & -0.022 & -0.115 & 0.022 & -0.009 & 1.000 & & & & & & \\
\hline 19 & University Affiliation & $0.206^{*}$ & 0.056 & $0.211^{*}$ & -0.101 & $-0.431 *$ & -0.022 & 1.000 & & & & & \\
\hline 20 & VC Backing & $0.252 *$ & $0.170^{*}$ & $0.188 *$ & 0.073 & 0.104 & $0.153^{*}$ & 0.000 & 1.000 & & & & \\
\hline 21 & PRESTIGE-SC & $0.507 *$ & $0.174 *$ & $0.234 *$ & 0.036 & -0.072 & 0.085 & $0.285^{*}$ & $0.287 *$ & 1.000 & & & \\
\hline 22 & PRESTIGE-UNI & $0.191 *$ & 0.117 & $0.199 *$ & -0.040 & $-0.347 *$ & -0.002 & $0.805^{*}$ & 0.004 & $0.303 *$ & 1.000 & & \\
\hline 23 & PRESTIGE-VC & 0.053 & -0.022 & -0.022 & 0.089 & -0.032 & 0.115 & 0.000 & $0.582 *$ & 0.094 & -0.046 & 1.000 & \\
\hline 24 & PRESTIGE-UW & -0.053 & -0.050 & -0.064 & -0.037 & 0.066 & $0.367 *$ & 0.000 & 0.000 & 0.020 & 0.021 & 0.011 & 1.000 \\
\hline
\end{tabular}


Table A5. Instrumental variable approach

This table reports the results of Instrumental Variable regressions on the valuation at the IPO measured through Tobin's Q. Model (3) is the outcome equation, estimated through a model with the same specification as Table 5, Model (1). Model (1) and (2) are the first stage estimates for PRESTIGE-VC and PRESTIGE-UW. The two instruments are VC EU-Activity and UW EU-Activity. VC EU-Activity is defined as the cumulative market capitalization of IPOs backed by the VC over the population of European IPOs (excluding biotech IPOs) in the period 1990-2009. UW EU-Activity is the share of IPOs taken public by a particular underwriter in the population of European IPOs (excluding biotech IPOs) in the period 1990-2009. All models include the Inverse Mills' Ratio (Prone to IPO - IMR) estimated in a first stage regression, where age, revenues, number of employees, time dummies, market and sub-industry dummies estimate the probability to go public (see Table A10). Controls for years, markets and sub-industries are included. Robust standard errors in parentheses. $* * *, * *$ and $*$ represent statistical significance at $0.01,0.05$ and 0.10 respectively.

\begin{tabular}{|c|c|c|c|c|c|}
\hline & $\begin{array}{c}(1) \\
\text { PRESTIGE-VC }\end{array}$ & $\begin{array}{c}(2) \\
\text { PRESTIGE-UW }\end{array}$ & $\begin{array}{c}(3) \\
\text { PRESTIGE-UNI } \\
\times \text { PRESTIGE-VC }\end{array}$ & $\begin{array}{c}(4) \\
\text { PRESTIGE-UNI } \\
\times \text { PRESTIGE-UW } \\
\end{array}$ & $\begin{array}{c}\text { (3) } \\
\text { TOBIN'S Q }\end{array}$ \\
\hline \multirow[t]{2}{*}{ Firm size } & 0.001 & 0.002 & 0.003 & $0.023 *$ & $-0.238 * * *$ \\
\hline & $(0.000)$ & $(0.002)$ & $(0.004)$ & $(0.012)$ & $(0.059)$ \\
\hline \multirow[t]{2}{*}{ Age } & -0.000 & -0.002 & 0.014 & -0.074 & -0.100 \\
\hline & $(0.005)$ & $(0.021)$ & $(0.040)$ & $(0.115)$ & $(0.536)$ \\
\hline \multirow[t]{2}{*}{ Profitability } & $-0.003 * *$ & -0.003 & 0.001 & -0.003 & $0.340 * *$ \\
\hline & $(0.001)$ & $(0.006)$ & $(0.011)$ & $(0.031)$ & $(0.144)$ \\
\hline \multirow[t]{2}{*}{ Leverage } & $-0.002 *$ & -0.001 & -0.003 & 0.001 & $0.456 * * *$ \\
\hline & $(0.001)$ & $(0.005)$ & $(0.009)$ & $(0.025)$ & $(0.117)$ \\
\hline \multirow[t]{2}{*}{ Dilution ratio } & 0.000 & $0.032 * *$ & 0.002 & -0.073 & 0.161 \\
\hline & $(0.003)$ & $(0.013)$ & $(0.024)$ & $(0.069)$ & $(0.326)$ \\
\hline \multirow[t]{2}{*}{ Participation ratio } & -0.002 & -0.002 & -0.017 & 0.114 & 1.192 \\
\hline & $(0.010)$ & $(0.045)$ & $(0.086)$ & $(0.250)$ & $(1.165)$ \\
\hline \multirow[t]{2}{*}{ Patents } & -0.002 & 0.007 & -0.011 & -0.015 & -0.094 \\
\hline & $(0.001)$ & $(0.006)$ & $(0.011)$ & $(0.033)$ & $(0.152)$ \\
\hline \multirow[t]{2}{*}{ UE size } & 0.003 & 0.007 & -0.006 & -0.034 & 0.005 \\
\hline & $(0.005)$ & $(0.022)$ & $(0.042)$ & $(0.123)$ & $(0.570)$ \\
\hline \multirow[t]{2}{*}{ UE with $\mathrm{PhD}$} & 0.007 & -0.054 & -0.088 & -0.288 & -1.783 \\
\hline & $(0.013)$ & $(0.056)$ & $(0.107)$ & $(0.309)$ & (1.443) \\
\hline \multirow[t]{2}{*}{ UE with MBA } & $-0.032 * *$ & -0.030 & -0.064 & -0.060 & -2.148 \\
\hline & $(0.012)$ & $(0.056)$ & $(0.105)$ & $(0.305)$ & $(1.423)$ \\
\hline \multirow[t]{2}{*}{ UE business exp. } & 0.015 & 0.005 & 0.247 & $-0.911^{*}$ & -0.568 \\
\hline & $(0.022)$ & $(0.100)$ & $(0.190)$ & $(0.549)$ & $(2.602)$ \\
\hline \multirow[t]{2}{*}{ Non-Executive Directors } & 0.018 & -0.011 & -0.027 & 0.002 & -2.285 \\
\hline & $(0.012)$ & $(0.055)$ & $(0.104)$ & $(0.300)$ & $(1.397)$ \\
\hline \multirow[t]{2}{*}{ Corporate spinoff } & -0.003 & 0.033 & -0.012 & -0.110 & 0.145 \\
\hline & $(0.005)$ & $(0.024)$ & $(0.046)$ & $(0.134)$ & $(0.631)$ \\
\hline \multirow{2}{*}{ Alliances } & 0.052 & 1.251 & 1.662 & 5.513 & $5.563 *$ \\
\hline & $(0.169)$ & $(0.759)$ & $(1.441)$ & $(4.169)$ & $(3.194)$ \\
\hline \multirow[t]{2}{*}{ University Affiliation } & 0.006 & 0.001 & -0.014 & 0.054 & -1.127 \\
\hline & $(0.009)$ & $(0.042)$ & $(0.080)$ & $(0.232)$ & (1.077) \\
\hline VC Backing & $0.065 * * *$ & -0.022 & 0.061 & $0.304 * *$ & -0.205 \\
\hline & $(0.006)$ & $(0.026)$ & $(0.049)$ & $(0.143)$ & $(0.747)$ \\
\hline Prone to IPO & -0.009 & 0.061 & -0.098 & -0.004 & -1.038 \\
\hline & $(0.028)$ & $(0.123)$ & $(0.234)$ & $(0.677)$ & $(3.153)$ \\
\hline PRESTIGE-UNI & -0.001 & -0.000 & $-0.117 * * *$ & $-0.040 *$ & $0.362 * * *$ \\
\hline & $(0.001)$ & $(0.004)$ & $(0.008)$ & $(0.023)$ & $(0.101)$ \\
\hline PRESTIGE-SC & 0.000 & 0.002 & 0.007 & 0.026 & $0.378 * * *$ \\
\hline & $(0.001)$ & $(0.004)$ & $(0.007)$ & $(0.020)$ & $(0.094)$ \\
\hline PRESTIGE-VC & - & - & - & - & $2.623^{* *}$ \\
\hline & & & & & $(1.314)$ \\
\hline PRESTIGE-UW & - & - & - & - & $5.306 * * *$ \\
\hline & & & & & $(1.680)$ \\
\hline PRESTIGE-UNI $\times$ PRESTIGE-SC & 0.000 & $0.002 *$ & 0.000 & $0.009 * *$ & $-0.059 * * *$ \\
\hline & $(0.000)$ & $(0.001)$ & $(0.002)$ & $(0.004)$ & $(0.021)$ \\
\hline PRESTIGE-UNI × PRESTIGE-VC & - & - & - & - & -0.338 \\
\hline & & & & & $(0.274)$ \\
\hline PRESTIGE-UNI $\times$ PRESTIGE-UW & - & - & - & - & -0.579 \\
\hline & & & & & $(0.583)$ \\
\hline VC EU-Activity & $0.931 * * *$ & -0.016 & -0.005 & $-0.566 * *$ & - \\
\hline & $(0.010)$ & $(0.047)$ & $(0.089)$ & $(0.257)$ & \\
\hline UW EU-Activity & 0.036 & $1.571 * *$ & 1.190 & $7.194 * *$ & - \\
\hline & $(0.136)$ & $(0.611)$ & $(1.160)$ & $(3.355)$ & \\
\hline PRESTIGE-UNI × VC EU-Activity & 0.002 & -0.015 & $1.008 * * *$ & $-0.160 * * *$ & - \\
\hline & $(0.002)$ & $(0.011)$ & $(0.020)$ & $(0.059)$ & \\
\hline PRESTIGE-UNI $\times$ UW EU-Activity & -0.006 & $0.048 * *$ & -0.005 & $0.971 * * *$ & - \\
\hline & $(0.005)$ & $(0.022)$ & $(0.042)$ & $(0.121)$ & \\
\hline Constant & $-0.117 * * *$ & -0.123 & -0.012 & 0.302 & $11.403 * * *$ \\
\hline & $(0.028)$ & $(0.124)$ & $(0.235)$ & $(0.681)$ & $(3.453)$ \\
\hline Observations & 254 & 254 & 254 & 254 & 254 \\
\hline R-squared & 0.684 & 0.338 & 0.624 & 0.352 & 0.440 \\
\hline Adjusted R-squared & 0.683 & 0.187 & 0.615 & 0.204 & 0.312 \\
\hline
\end{tabular}


Table A6. Alternative definitions for Prestige

Models (1-6) are OLS regressions on valuation at the IPO measured through Tobin's Q. All models replicate Model (5) in Table 5, replacing one measure of prestige. Model (1-2) include alternative measures of University Prestige. PRESTIGE-UNI is defined in model (1) according to the Annual Ranking of World Universities (ARWU) published by the Jiao Tong University in Shanghai (PRESTIGE-UNI=Ranking ${ }^{-1}$ when the ranking is available, 0 otherwise); in model (2) by a dummy variable equal to 1 for universities listed in the Milken Ranking of universities in the biotech field, 0 otherwise Model (3-4) include an alternative measures of Scientific Prestige: PRESTIGE-SC is defined in model (3) as the total number of papers ("articles") published by members of the TMT of a certain IPO firm in the twenty years before the IPO year in biotech-related fields (see Table 2), normalized by mean and standard deviation of all sample articles published in each year, and transformed into natural logarithms; in model (4) as the total number of top papers ("articles" published on Nature, Science and Cell) published by members of the TMT of a certain IPO firm in the twenty years before the IPO year, normalized by mean and standard deviation of all sampled top articles in each year, and transformed into natural logarithms. Model (5-6) include alternative measures of VC Prestige: PRESTIGE-VC is defined in Model (5) as the value of LPJ Reputation Index 2001-2010 available at Timothy Pollock's website; in Model (6) by a dummy variable equal to 1 for all the VCs with above-median value of LPJ Reputation Index 2001-2010 available at Timothy Pollock's website, 0 otherwise. Model (7-8) include alternative measures of UW Prestige. PRESTIGE-UW is defined in Model (7) as the share of IPOs taken public by a particular underwriter in sample IPOs; in Model (8) as the Carter Manaster ranking (1990) in Model. All models include the Inverse Mills' Ratio (Prone to IPO - IMR) estimated in a first stage regression, where age, revenues, number of employees, time dummies, market and sub-industry dummies estimate the probability to go public (see Table A10). Controls for years, markets and sub-industries are included. Robust standard errors in parentheses. $* * * * *$ and $*$ represent statistical significance at $0.01,0.05$ and 0.10 respectively.

\begin{tabular}{|c|c|c|c|c|c|c|c|c|}
\hline & (1) & (2) & (3) & (4) & (5) & (6) & (7) & (8) \\
\hline Firm size & $\begin{array}{c}-0.241 * * * \\
(0.059)\end{array}$ & $\begin{array}{c}-0.257 * * * \\
(0.058)\end{array}$ & $\begin{array}{c}-0.265^{* * * *} \\
(0.058)\end{array}$ & $\begin{array}{c}-0.265^{* * *} * \\
(0.059)\end{array}$ & $\begin{array}{c}-0.252 * * * \\
(0057)\end{array}$ & $-0.255^{* * *} *$ & $-0.249 * * * *$ & $\begin{array}{c}-0.255^{* * *} * \\
(0.057)\end{array}$ \\
\hline Age & $\begin{array}{c}-0.362 \\
(0.542)\end{array}$ & $\begin{array}{l}-0.200 \\
(0.550)\end{array}$ & $\begin{array}{c}0.051 \\
(0.554)\end{array}$ & $\begin{array}{l}-0.004 \\
(0.555)\end{array}$ & $\begin{array}{l}-0.079 \\
(0.535)\end{array}$ & $\begin{array}{l}-0.102 \\
(0.539)\end{array}$ & $\begin{array}{c}0.030 \\
(0.537)\end{array}$ & $\begin{array}{l}-0.083 \\
(0.540)\end{array}$ \\
\hline Profitability & $\begin{array}{c}0.317 * * \\
(0.147)\end{array}$ & $\begin{array}{c}0.339 * * \\
(0.148)\end{array}$ & $\begin{array}{l}0.276^{*} \\
(0.146)\end{array}$ & $\begin{array}{c}0.245 \\
(0.149)\end{array}$ & $\begin{array}{c}0.333 * * \\
(0.144)\end{array}$ & $\begin{array}{c}0.348 * * \\
(0.144)\end{array}$ & $\begin{array}{c}0.383 * * * \\
(0.145)\end{array}$ & $\begin{array}{c}0.334 * * \\
(0.145)\end{array}$ \\
\hline Leverage & $\begin{array}{c}0.466 * * * \\
(0.119)\end{array}$ & $\begin{array}{c}0.475^{* * *} * \\
(0.120)\end{array}$ & $\begin{array}{c}0.403^{* * *} * \\
(0.120)\end{array}$ & $\begin{array}{c}0.398 * * * \\
(0.121)\end{array}$ & $\begin{array}{c}0.445^{* * *} \\
(0.117)\end{array}$ & $\begin{array}{c}0.439 * * * \\
(0.118)\end{array}$ & $\begin{array}{c}0.457 * * * \\
(0.117)\end{array}$ & $\begin{array}{c}0.461 * * * \\
(0.118)\end{array}$ \\
\hline Dilution ratio & $\begin{array}{c}0.181 \\
(0.331)\end{array}$ & $\begin{array}{c}0.124 \\
(0.336)\end{array}$ & $\begin{array}{l}-0.028 \\
(0.331)\end{array}$ & $\begin{array}{c}0.002 \\
(0.332)\end{array}$ & $\begin{array}{c}0.220 \\
(0.326)\end{array}$ & $\begin{array}{c}0.284 \\
(0.326)\end{array}$ & $\begin{array}{c}0.412 \\
(0.319)\end{array}$ & $\begin{array}{c}0.373 \\
(0.321)\end{array}$ \\
\hline Participation ratio & $\begin{array}{l}1.008 \\
(1.181)\end{array}$ & $\begin{array}{c}0.967 \\
(1.190)\end{array}$ & $\begin{array}{l}1.684 \\
(1.192)\end{array}$ & $\begin{array}{l}2.118^{*} \\
(1.173)\end{array}$ & $\begin{array}{l}1.082 \\
(1.161)\end{array}$ & $\begin{array}{c}0.956 \\
(1.166)\end{array}$ & $\begin{array}{c}1.462 \\
(1.176)\end{array}$ & $\begin{array}{l}1.053 \\
(1.173)\end{array}$ \\
\hline Patents & $\begin{array}{l}-0.164 \\
(0.155)\end{array}$ & $\begin{array}{l}-0.129 \\
(0.155)\end{array}$ & $\begin{array}{l}-0.065 \\
(0.158)\end{array}$ & $\begin{array}{l}-0.024 \\
(0.157)\end{array}$ & $\begin{array}{l}-0.084 \\
(0.152)\end{array}$ & $\begin{array}{l}-0.084 \\
(0.154)\end{array}$ & $\begin{array}{l}-0.038 \\
(0.152)\end{array}$ & $\begin{array}{l}-0.031 \\
(0.153)\end{array}$ \\
\hline UE size & $\begin{array}{c}0.177 \\
(0.577)\end{array}$ & $\begin{array}{c}0.133 \\
(0.585)\end{array}$ & $\begin{array}{c}0.171 \\
(0.586)\end{array}$ & $\begin{array}{c}0.183 \\
(0.590)\end{array}$ & $\begin{array}{c}0.037 \\
(0.569)\end{array}$ & $\begin{array}{l}-0.010 \\
(0.572)\end{array}$ & $\begin{array}{c}0.082 \\
(0.571)\end{array}$ & $\begin{array}{c}0.060 \\
(0.575)\end{array}$ \\
\hline UE with PhD & $\begin{array}{l}-1.735 \\
(1.462)\end{array}$ & $\begin{array}{l}-1.902 \\
(1.471)\end{array}$ & $\begin{array}{l}-0.951 \\
(1.520)\end{array}$ & $\begin{array}{l}-0.391 \\
(1.482)\end{array}$ & $\begin{array}{l}-1.848 \\
(1.437)\end{array}$ & $\begin{array}{l}-1.919 \\
(1.447)\end{array}$ & $\begin{array}{l}-1.887 \\
(1.439)\end{array}$ & $\begin{array}{l}-1.916 \\
(1.450)\end{array}$ \\
\hline UE with MBA & $\begin{array}{l}-1.751 \\
(1.439)\end{array}$ & $\begin{array}{l}-1.609 \\
(1.447)\end{array}$ & $\begin{array}{l}-2.332 \\
(1.462)\end{array}$ & $\begin{array}{l}-2.451^{*} \\
(1.467)\end{array}$ & $\begin{array}{l}-2.096 \\
(1.421)\end{array}$ & $\begin{array}{l}-2.109 \\
(1.431)\end{array}$ & $\begin{array}{l}-2.251 \\
(1.423)\end{array}$ & $\begin{array}{l}-2.416^{*} \\
(1.436)\end{array}$ \\
\hline UE business exp. & $\begin{array}{c}0.576 \\
(2.603)\end{array}$ & $\begin{array}{c}0.544 \\
(2.623)\end{array}$ & $\begin{array}{l}-0.064 \\
(2.675)\end{array}$ & $\begin{array}{l}-0.239 \\
(2.687)\end{array}$ & $\begin{array}{c}0.087 \\
(2.560)\end{array}$ & $\begin{array}{l}-0.194 \\
(2.571)\end{array}$ & $\begin{array}{c}0.488 \\
(2.566)\end{array}$ & $\begin{array}{c}0.191 \\
(2.585)\end{array}$ \\
\hline Non-Executive Dir. & $\begin{array}{l}-2.283 \\
(1.419)\end{array}$ & $\begin{array}{l}-2.020 \\
(1.423)\end{array}$ & $\begin{array}{l}-2.003 \\
(1.438)\end{array}$ & $\begin{array}{l}-1.971 \\
(1.445)\end{array}$ & $\begin{array}{l}-2.330^{*} \\
(1.392)\end{array}$ & $\begin{array}{l}-2.065 \\
(1.393)\end{array}$ & $\begin{array}{l}-2.473^{*} \\
(1.395)\end{array}$ & $\begin{array}{l}-2.221 \\
(1.411)\end{array}$ \\
\hline Corporate spinoff & $\begin{array}{c}0.049 \\
(0.639)\end{array}$ & $\begin{array}{c}0.095 \\
(0.643)\end{array}$ & $\begin{array}{c}0.219 \\
(0.649)\end{array}$ & $\begin{array}{c}0.192 \\
(0.652)\end{array}$ & $\begin{array}{c}0.198 \\
(0.628)\end{array}$ & $\begin{array}{c}0.104 \\
(0.631)\end{array}$ & $\begin{array}{c}0.405 \\
(0.626)\end{array}$ & $\begin{array}{c}0.365 \\
(0.631)\end{array}$ \\
\hline Alliances & $\begin{array}{c}5.174 \\
(3.264)\end{array}$ & $\begin{array}{c}5.301 \\
(3.292)\end{array}$ & $\begin{array}{l}5.215 \\
(3.327)\end{array}$ & $\begin{array}{c}5.375 \\
(3.354)\end{array}$ & $\begin{array}{l}5.598^{*} \\
(3.219)\end{array}$ & $\begin{array}{l}5.590 * \\
(3.247)\end{array}$ & $\begin{array}{c}2.252 \\
(2.998)\end{array}$ & $\begin{array}{c}4.943 \\
(3.502)\end{array}$ \\
\hline University Affiliation & $\begin{array}{l}1.184 \\
(0.780)\end{array}$ & $\begin{array}{l}1.284 \\
(0.807)\end{array}$ & $\begin{array}{l}-1.167 \\
(1.114)\end{array}$ & $\begin{array}{l}-1.048 \\
(1.119)\end{array}$ & $\begin{array}{l}-1.259 \\
(1.078)\end{array}$ & $\begin{array}{l}-1.112 \\
(1.080)\end{array}$ & $\begin{array}{l}-1.516 \\
(1.083)\end{array}$ & $\begin{array}{l}-1.133 \\
(1.087)\end{array}$ \\
\hline VC Backing & $\begin{array}{l}-0.491 \\
(0.729)\end{array}$ & $\begin{array}{l}-0.514 \\
(0.736)\end{array}$ & $\begin{array}{l}-0.574 \\
(0.751)\end{array}$ & $\begin{array}{l}-0.389 \\
(0.744)\end{array}$ & $\begin{array}{l}-0.714 \\
(0.791)\end{array}$ & $\begin{array}{l}-0.447 \\
(0.849)\end{array}$ & $\begin{array}{l}-0.659 \\
(0.715)\end{array}$ & $\begin{array}{l}-0.729 \\
(0.720)\end{array}$ \\
\hline Prone to IPO & $\begin{array}{l}-1.844 \\
(3.208)\end{array}$ & $\begin{array}{l}-1.141 \\
(3.232)\end{array}$ & $\begin{array}{l}-0.666 \\
(3.355)\end{array}$ & $\begin{array}{l}-0.809 \\
(3.372)\end{array}$ & $\begin{array}{l}-1.070 \\
(3.154)\end{array}$ & $\begin{array}{l}-1.473 \\
(3.163)\end{array}$ & $\begin{array}{l}-1.273 \\
(3.159)\end{array}$ & $\begin{array}{l}-0.581 \\
(3.183)\end{array}$ \\
\hline PRESTIGE-UNI & $\begin{array}{c}14.168 * * \\
(6.223)\end{array}$ & $\begin{array}{l}2.228^{*} \\
(1.262)\end{array}$ & $\begin{array}{c}0.402 * * * \\
(0.103)\end{array}$ & $\begin{array}{c}0.391 * * * \\
(0.104)\end{array}$ & $\begin{array}{c}0.366^{* * * *} \\
(0.101)\end{array}$ & $\begin{array}{c}0.345^{* * * *} \\
(0.101)\end{array}$ & $\begin{array}{c}0.414 * * * \\
(0.102)\end{array}$ & $\begin{array}{c}0.364 * * * \\
(0.102)\end{array}$ \\
\hline PRESTIGE-SC & $\begin{array}{c}0.397 * * * \\
(0.094)\end{array}$ & $\begin{array}{c}0.403 * * * \\
(0.095)\end{array}$ & $\begin{array}{c}0.347 * * \\
(0.169)\end{array}$ & $\begin{array}{c}0.391 * * * \\
(0.104)\end{array}$ & $\begin{array}{c}0.375^{* * *} \\
(0.093)\end{array}$ & $\begin{array}{c}0.371 * * * \\
(0.094)\end{array}$ & $\begin{array}{c}0.360 * * * \\
(0.094)\end{array}$ & $\begin{array}{c}0.367 * * * \\
(0.094)\end{array}$ \\
\hline PRESTIGE-VC & $\begin{array}{l}2.653 * * \\
(1.284)\end{array}$ & $\begin{array}{c}2.674 * * \\
(1.298)\end{array}$ & $\begin{array}{c}2.908^{* *} \\
(1.302)\end{array}$ & $\begin{array}{c}2.891 * * \\
(1.309)\end{array}$ & $\begin{array}{l}1.031 * * \\
(0.454)\end{array}$ & $\begin{array}{l}1.383^{*} \\
(0.785)\end{array}$ & $\begin{array}{c}3.101 * * \\
(1.269)\end{array}$ & $\begin{array}{c}2.890 * * \\
(1.283)\end{array}$ \\
\hline PRESTIGE-UW & $\begin{array}{c}5.133 * * * \\
(1.790)\end{array}$ & $\begin{array}{c}4.923 * * * \\
(1.804)\end{array}$ & $\begin{array}{c}4.849^{* *} * \\
(1.884)\end{array}$ & $\begin{array}{c}5.018 * * * \\
(1.891)\end{array}$ & $\begin{array}{c}4.917 * * * \\
(1.760)\end{array}$ & $\begin{array}{c}4.674 * * * \\
(1.778)\end{array}$ & $\begin{array}{c}2.274 * * \\
(0.923)\end{array}$ & $\begin{array}{l}1.501^{*} \\
(0.894)\end{array}$ \\
\hline PRESTIGE-UNI $\times$ PRESTIGE-SC & $\begin{array}{c}-0.059 * * * \\
(0.021)\end{array}$ & $\begin{array}{c}-0.058 * * * \\
(0.022)\end{array}$ & $\begin{array}{c}-0.060 * * * \\
(0.021)\end{array}$ & $\begin{array}{c}-0.057 * * * * \\
(0.021)\end{array}$ & $\begin{array}{c}-0.064 * * * \\
(0.021)\end{array}$ & $\begin{array}{c}-0.066^{* * *} * \\
(0.021)\end{array}$ & $\begin{array}{c}-0.059 * * * \\
(0.021)\end{array}$ & $\begin{array}{c}-0.061 * * * \\
(0.021)\end{array}$ \\
\hline PRESTIGE-UNI $\times$ PRESTIGE-VC & $\begin{array}{l}-0.310 \\
(0.265)\end{array}$ & $\begin{array}{l}-0.332 \\
(0.270)\end{array}$ & $\begin{array}{l}-0.384 \\
(0.263)\end{array}$ & $\begin{array}{l}-0.390 \\
(0.265)\end{array}$ & $\begin{array}{l}-0.330 \\
(0.255)\end{array}$ & $\begin{array}{l}-0.398 \\
(0.254)\end{array}$ & $\begin{array}{l}-0.350 \\
(0.258)\end{array}$ & $\begin{array}{c}-0.443 * \\
(0.259)\end{array}$ \\
\hline PRESTIGE-UNI $\times$ PRESTIGE-UW & $\begin{array}{c}0.098 \\
(0.293)\end{array}$ & $\begin{array}{c}0.124 \\
(0.295)\end{array}$ & $\begin{array}{c}0.182 \\
(0.301)\end{array}$ & $\begin{array}{c}0.093 \\
(0.302)\end{array}$ & $\begin{array}{c}0.146 \\
(0.288)\end{array}$ & $\begin{array}{c}0.107 \\
(0.289)\end{array}$ & $\begin{array}{c}0.337 \\
(0.272)\end{array}$ & $\begin{array}{c}0.328 \\
(0.277)\end{array}$ \\
\hline Constant & $\begin{array}{c}10.420 * * * \\
(3.188)\end{array}$ & $\begin{array}{c}9.940 * * * \\
(3.220)\end{array}$ & $\begin{array}{c}8.340^{* * *} \\
(3.238)\end{array}$ & $\begin{array}{c}8.770 * * * \\
(3.240)\end{array}$ & $\begin{array}{c}10.225^{* * * *} \\
(3.174)\end{array}$ & $\begin{array}{c}10.839 * * * \\
(3.175)\end{array}$ & $\begin{array}{c}8.763 * * * \\
(3.182)\end{array}$ & $\begin{array}{c}9.928 * * * \\
(3.160)\end{array}$ \\
\hline Observations & 254 & 254 & 254 & 254 & 254 & 254 & 254 & 254 \\
\hline R-squared & 0.431 & 0.423 & 0.434 & 0.430 & 0.456 & 0.453 & 0.456 & 0.457 \\
\hline
\end{tabular}


Table A7. Alternative dependent variables

Models are OLS regressions on valuation at the IPO measured through EV/Sales (Models 1-2) and on Underpricing at the IPO (Models 3-4). VC Affiliation are the residuals after regressing the variable against University affiliation, PRESTIGE-UNI, PRESTIGE-SC, country and year control variables; Prestige$V C$ are the residuals after regressing the variable against: University affiliation, PRESTIGE-UNI, PRESTIGE-SC, country and year control variables; Prestige-UW are the residuals after regressing the variable against: University affiliation, PRESTIGE-UNI, PRESTIGE-SC, VC Backing, Prestige-VC, country and year control variables. All models include the Inverse Mills' Ratio (Prone to IPO - IMR) estimated in a first stage regression, where age, revenues, number of employees, time dummies, market and sub-industry dummies estimate the probability to go public (see Table A10). Controls for years, markets and sub-industries are included. Robust standard errors in parentheses. ***, ** and * represent statistical significance at $0.01,0.05$ and 0.10 respectively.

\begin{tabular}{|c|c|c|c|c|}
\hline & $\begin{array}{c}(1) \\
\text { EV/sales }\end{array}$ & $\begin{array}{c}(2) \\
\text { EV/Sales }\end{array}$ & $\begin{array}{c}(3) \\
\text { Underpricing }\end{array}$ & $\begin{array}{c}\text { (4) } \\
\text { Underpricing }\end{array}$ \\
\hline \multirow[t]{2}{*}{ Firm size } & $-0.362 * * *$ & $-0.372 * * *$ & -0.005 & -0.005 \\
\hline & $(0.042)$ & $(0.042)$ & $(0.013)$ & $(0.013)$ \\
\hline \multirow[t]{2}{*}{ Age } & -0.441 & -0.424 & 0.048 & 0.106 \\
\hline & $(0.390)$ & $(0.385)$ & $(0.122)$ & $(0.123)$ \\
\hline \multirow[t]{2}{*}{ Profitability } & 0.016 & 0.026 & -0.015 & -0.018 \\
\hline & $(0.105)$ & $(0.104)$ & $(0.033)$ & $(0.033)$ \\
\hline \multirow[t]{2}{*}{ Leverage } & $0.181 * *$ & $0.169 * *$ & -0.013 & -0.010 \\
\hline & $(0.086)$ & $(0.084)$ & $(0.027)$ & $(0.027)$ \\
\hline \multirow[t]{2}{*}{ Dilution ratio } & -0.083 & -0.110 & -0.079 & -0.098 \\
\hline & $(0.236)$ & $(0.233)$ & $(0.074)$ & $(0.077)$ \\
\hline \multirow[t]{2}{*}{ Participation ratio } & $1.587^{*}$ & $1.571^{*}$ & -0.020 & 0.041 \\
\hline & $(0.849)$ & $(0.835)$ & $(0.267)$ & $(0.269)$ \\
\hline \multirow[t]{2}{*}{ Patents } & 0.170 & 0.125 & 0.056 & 0.056 \\
\hline & $(0.110)$ & $(0.109)$ & $(0.035)$ & $(0.035)$ \\
\hline \multirow[t]{2}{*}{ UE size } & 0.076 & 0.033 & 0.098 & 0.076 \\
\hline & $(0.420)$ & $(0.413)$ & $(0.130)$ & $(0.131)$ \\
\hline \multirow[t]{2}{*}{ UE with Ph.D. } & 1.127 & 0.972 & -0.027 & -0.011 \\
\hline & (1.041) & (1.033) & $(0.331)$ & $(0.334)$ \\
\hline \multirow[t]{2}{*}{ UE with MBA } & -1.578 & -1.463 & -0.075 & -0.077 \\
\hline & (1.039) & $(1.023)$ & $(0.326)$ & $(0.327)$ \\
\hline \multirow[t]{2}{*}{ UE business experience } & -0.351 & -0.080 & 0.412 & 0.445 \\
\hline & $(1.874)$ & $(1.845)$ & $(0.583)$ & $(0.585)$ \\
\hline \multirow[t]{2}{*}{ Non-Executive Directors } & 1.239 & 1.151 & -0.208 & -0.175 \\
\hline & $(1.014)$ & $(0.997)$ & $(0.317)$ & $(0.320)$ \\
\hline \multirow[t]{2}{*}{ Corporate spinoff } & -0.459 & -0.377 & 0.153 & 0.152 \\
\hline & $(0.459)$ & $(0.454)$ & $(0.143)$ & $(0.144)$ \\
\hline \multirow[t]{2}{*}{ Alliances } & 4.657 & 4.600 & 2.220 & 2.186 \\
\hline & $(3.340)$ & $(3.311)$ & $(2.732)$ & $(1.733)$ \\
\hline \multirow[t]{2}{*}{ University Affiliation } & -0.577 & -0.425 & $-0.295^{*}$ & $-0.435^{* *}$ \\
\hline & $(0.716)$ & $(0.733)$ & $(0.166)$ & $(0.174)$ \\
\hline \multirow{2}{*}{ VC Backing } & 0.340 & 0.295 & -0.213 & -0.218 \\
\hline & $(0.468)$ & $(0.460)$ & $(0.155)$ & $(0.156)$ \\
\hline \multirow[t]{2}{*}{ Prone to IPO (IMR) } & -0.028 & 0.131 & $1.187^{*}$ & $1.238^{*}$ \\
\hline & $(2.316)$ & $(2.278)$ & $(0.719)$ & $(0.721)$ \\
\hline \multirow[t]{2}{*}{ PRESTIGE-UNI } & $0.149 * *$ & $0.160 * *$ & $-0.055^{* * *}$ & $-0.062 * * *$ \\
\hline & $(0.067)$ & $(0.066)$ & $(0.019)$ & $(0.019)$ \\
\hline \multirow[t]{2}{*}{ PRESTIGE-SC } & $0.135^{* *}$ & $0.168 * *$ & $-0.049 * *$ & $-0.053 * *$ \\
\hline & $(0.066)$ & $(0.066)$ & $(0.021)$ & $(0.021)$ \\
\hline \multirow[t]{2}{*}{ PRESTIGE-VC } & $2.007 * * *$ & $2.005^{* * *}$ & $-0.623 * *$ & $-0.621 * *$ \\
\hline & $(0.736)$ & $(0.724)$ & $(0.265)$ & $(0.265)$ \\
\hline PRESTIGE-UW & $2.404 * *$ & $2.830 * *$ & $-0.683^{*}$ & $-0.546^{*}$ \\
\hline & $(1.210)$ & $(1.198)$ & $(0.376)$ & $(0.281)$ \\
\hline PRESTIGE-UNI $\times$ PRESTIGE-SC & - & $-0.037 * *$ & - & $0.011 * *$ \\
\hline & & $(0.015)$ & & $(0.005)$ \\
\hline PRESTIGE-UNI $\times$ PRESTIGE-VC & - & -24.033 & - & -4.659 \\
\hline & & $(15.083)$ & & $(4.889)$ \\
\hline PRESTIGE-UNI $\times$ PRESTIGE-UW & - & 46.212 & - & -1.389 \\
\hline & & $(38.299)$ & & $(1.059)$ \\
\hline Constant & $7.715^{* * *}$ & $8.006^{* * *}$ & -0.768 & -1.001 \\
\hline & $(2.320)$ & $(2.284)$ & $(0.715)$ & $(0.717)$ \\
\hline Observations & 254 & 254 & 254 & 254 \\
\hline R-squared & 0.614 & 0.631 & 0.263 & 0.287 \\
\hline Adjusted R-squared & 0.532 & 0.547 & 0.108 & 0.124 \\
\hline
\end{tabular}




\section{Table A8. Robustness on signals interactions}

Models (1-3) are OLS regressions on valuation at the IPO measured through Tobin's Q. The reference specification is that of Table 5, Model (5). Models (1) include the interaction between PRESTIGE-SC and PRESTIGE-VC. Model (2) includes the interaction between PRESTIGE-SC and PRESTIGE-UW. Model (3) includes the interaction between PRESTIGE-VC and PRESTIGE-UW. VC Affiliation are the residuals after regressing the variable against University affiliation, PRESTIGE-UNI, PRESTIGE-SC, country and year control variables; Prestige-VC are the residuals after regressing the variable against: University affiliation, PRESTIGE-UNI, PRESTIGE-SC, country and year control variables; Prestige-UW are the residuals after regressing the variable against: University affiliation, PRESTIGE-UNI, PRESTIGE-SC, VC Backing, Prestige-VC, country and year control variables. All models include the Inverse Mills' Ratio (Prone to IPO - IMR) estimated in a first stage regression, where age, revenues, number of employees, time dummies, market and sub-industry dummies estimate the probability to go public (see Table A10). Controls for years, markets and sub-industries are included. Robust standard errors in parentheses. $* * *, * *$ and $*$ represent statistical significance at $0.01,0.05$ and 0.10 respectively.

\begin{tabular}{|c|c|c|c|}
\hline & (1) & (2) & (3) \\
\hline \multirow[t]{2}{*}{ Firm size } & $-0.255^{* * *}$ & $-0.254 * * *$ & $-0.247 * * *$ \\
\hline & $(0.063)$ & $(0.064)$ & $(0.063)$ \\
\hline \multirow[t]{2}{*}{ Age } & -0.090 & -0.081 & -0.129 \\
\hline & $(0.515)$ & $(0.514)$ & $(0.512)$ \\
\hline \multirow[t]{2}{*}{ Profitability } & $0.350 * * *$ & $0.346 * * *$ & $0.332 * * *$ \\
\hline & $(0.107)$ & $(0.106)$ & $(0.105)$ \\
\hline \multirow[t]{2}{*}{ Leverage } & $0.460 * * *$ & $0.457 * * *$ & $0.451^{* * *} *$ \\
\hline & $(0.096)$ & $(0.095)$ & $(0.092)$ \\
\hline \multirow[t]{2}{*}{ Dilution ratio } & 0.225 & 0.213 & 0.197 \\
\hline & $(0.558)$ & $(0.568)$ & $(0.586)$ \\
\hline \multirow[t]{2}{*}{ Participation ratio } & 1.052 & 1.109 & 1.027 \\
\hline & $(0.915)$ & $(0.908)$ & $(0.904)$ \\
\hline \multirow[t]{2}{*}{ Patents } & -0.079 & -0.081 & -0.036 \\
\hline & $(0.144)$ & $(0.146)$ & $(0.146)$ \\
\hline \multirow[t]{2}{*}{ UE size } & 0.059 & 0.041 & 0.027 \\
\hline & $(0.592)$ & $(0.586)$ & $(0.584)$ \\
\hline \multirow[t]{2}{*}{ UE with $\mathrm{PhD}$} & -1.596 & -1.665 & -1.451 \\
\hline & $(1.522)$ & $(1.546)$ & $(1.520)$ \\
\hline \multirow{2}{*}{ UE with MBA } & -2.067 & -2.116 & -1.930 \\
\hline & (1.383) & $(1.389)$ & $(1.396)$ \\
\hline \multirow[t]{2}{*}{ UE business exp. } & 0.174 & 0.123 & -0.009 \\
\hline & $(2.670)$ & $(2.674)$ & $(2.621)$ \\
\hline \multirow[t]{2}{*}{ Non-Executive Directors } & $-2.371^{*}$ & $-2.349 *$ & -2.133 \\
\hline & $(1.301)$ & $(1.289)$ & $(1.293)$ \\
\hline \multirow{2}{*}{ Corporate spinoff } & 0.213 & 0.230 & 0.177 \\
\hline & $(0.610)$ & $(0.609)$ & $(0.606)$ \\
\hline \multirow[t]{2}{*}{ Alliances } & 5.150 & 5.151 & 4.778 \\
\hline & $(3.938)$ & $(3.949)$ & $(3.898)$ \\
\hline \multirow[t]{2}{*}{ University Affiliation } & -1.252 & -1.205 & -0.918 \\
\hline & $(1.463)$ & $(1.467)$ & $(1.485)$ \\
\hline \multirow[t]{2}{*}{ VC Backing } & -0.476 & -0.482 & -0.442 \\
\hline & $(0.780)$ & $(0.780)$ & $(0.768)$ \\
\hline \multirow[t]{2}{*}{ Prone to IPO } & -1.133 & -1.106 & -1.140 \\
\hline & $(2.375)$ & $(2.418)$ & $(2.391)$ \\
\hline \multirow[t]{2}{*}{ PRESTIGE-UNI } & $0.373 * * *$ & $0.370 * * *$ & $0.346^{* *}$ \\
\hline & $(0.136)$ & $(0.137)$ & $(0.137)$ \\
\hline PRESTIGE-SC & $0.370 * * *$ & $0.371 * * *$ & $0.344 * * *$ \\
\hline & $(0.099)$ & $(0.099)$ & $(0.099)$ \\
\hline PRESTIGE-VC & $2.920 * *$ & $2.961 * *$ & $2.373^{*}$ \\
\hline & $(1.417)$ & $(1.438)$ & $(1.372)$ \\
\hline PRESTIGE-UW & $4.825 * *$ & $4.795 * *$ & $3.994 *$ \\
\hline & $(2.237)$ & $(2.250)$ & $(2.253)$ \\
\hline PRESTIGE-UNI $\times$ PRESTIGE-SC & $-0.065 * * *$ & $-0.065^{* * *}$ & $-0.068 * * *$ \\
\hline & $(0.024)$ & $(0.024)$ & $(0.024)$ \\
\hline PRESTIGE-UNI × PRESTIGE-VC & -0.452 & -0.401 & -0.491 \\
\hline & $(0.348)$ & $(0.341)$ & $(0.330)$ \\
\hline PRESTIGE-UNI $\times$ PRESTIGE-UW & 0.152 & 0.124 & 0.113 \\
\hline & $(0.256)$ & $(0.372)$ & $(0.253)$ \\
\hline PRESTIGE-SC $\times$ PRESTIGE-VC & 0.145 & - & - \\
\hline & $(0.319)$ & & \\
\hline PRESTIGE-SC $\times$ PRESTIGE-UW & - & $\begin{array}{c}0.036 \\
(0.587)\end{array}$ & - \\
\hline PRESTIGE-VC $\times$ PRESTIGE-UW & - & - & $\begin{array}{c}-4.962 * \\
(2.895)\end{array}$ \\
\hline Constant & $10.679 * * *$ & $10.657 * * *$ & $10.508 * * *$ \\
\hline & $(2.846)$ & $(2.904)$ & $(2.830)$ \\
\hline Observations & 254 & 254 & 254 \\
\hline R-squared & 0.460 & 0.461 & 0.476 \\
\hline Adjusted R-squared & 0.333 & 0.335 & 0.353 \\
\hline
\end{tabular}




\section{Table A9. University Ownership and VC Syndication}

Models (1-2) are OLS regressions on valuation at the IPO measured through Tobin's Q. Model (1) adds University Ownership (dummy variable equal to 1 if the University holds a stake in the IPO firm) to the specification in Table 5, Model (5). Model (2) adds VC Syndicate (dummy variable equal to 1 if more than one VC is investing in the company) to the specification in Table 5, Model (5). VC Affiliation are the residuals after regressing the variable against University affiliation, PRESTIGE-UNI, PRESTIGE-SC, country and year control variables; Prestige-VC are the residuals after regressing the variable against: University affiliation, PRESTIGE-UNI, PRESTIGE-SC, country and year control variables; Prestige-UW are the residuals after regressing the variable against: University affiliation, PRESTIGE-UNI, PRESTIGE-SC, VC Backing, Prestige-VC, country and year control variables. All models include the Inverse Mills' Ratio (Prone to IPO - IMR) estimated in a first stage regression, where age, revenues, number of employees, time dummies, market and sub-industry dummies estimate the probability to go public (see Table A10). Controls for years, markets and sub-industries are included. Robust standard errors in parentheses. $* * *, * *$ and $*$ represent statistical significance at $0.01,0.05$ and 0.10 respectively.

\begin{tabular}{|c|c|c|}
\hline & (1) & (2) \\
\hline Firm size & $\begin{array}{c}-0.251 * * * \\
(0.057)\end{array}$ & $\begin{array}{c}-0.251 * * * \\
(0.057)\end{array}$ \\
\hline Age & $\begin{array}{l}-0.101 \\
(0.536)\end{array}$ & $\begin{array}{l}-0.095 \\
(0.535)\end{array}$ \\
\hline Profitability & $\begin{array}{c}0.339 * * \\
(0.144)\end{array}$ & $\begin{array}{c}0.341^{* *} \\
(0.144)\end{array}$ \\
\hline Leverage & $\begin{array}{c}0.459 * * * \\
(0.117)\end{array}$ & $\begin{array}{c}0.460 * * * \\
(0.117)\end{array}$ \\
\hline Dilution ratio & $\begin{array}{c}0.210 \\
(0.326)\end{array}$ & $\begin{array}{c}0.195 \\
(0.326)\end{array}$ \\
\hline Participation ratio & $\begin{array}{c}1.117 \\
(1.163)\end{array}$ & $\begin{array}{c}1.047 \\
(1.165)\end{array}$ \\
\hline Patents & $\begin{array}{l}-0.090 \\
(0.153)\end{array}$ & $\begin{array}{c}-0.088 \\
(0.152)\end{array}$ \\
\hline UE size & $\begin{array}{c}0.082 \\
(0.572)\end{array}$ & $\begin{array}{c}0.018 \\
(0.570)\end{array}$ \\
\hline UE with PhD & $\begin{array}{l}-1.679 \\
(1.438)\end{array}$ & $\begin{array}{l}-1.926 \\
(1.466)\end{array}$ \\
\hline UE with MBA & $\begin{array}{l}-2.093 \\
(1.421)\end{array}$ & $\begin{array}{l}-1.932 \\
(1.436)\end{array}$ \\
\hline UE business exp. & $\begin{array}{c}0.345 \\
(2.581)\end{array}$ & $\begin{array}{c}0.097 \\
(2.561)\end{array}$ \\
\hline Non-Executive Directors & $\begin{array}{l}-2.222 \\
(1.403)\end{array}$ & $\begin{array}{l}-2.226 \\
(1.399)\end{array}$ \\
\hline Corporate spinoff & $\begin{array}{c}0.219 \\
(0.629)\end{array}$ & $\begin{array}{c}0.214 \\
(0.629)\end{array}$ \\
\hline Alliances & $\begin{array}{c}4.978 \\
(3.218)\end{array}$ & $\begin{array}{c}5.493 \\
(4.236)\end{array}$ \\
\hline University Affiliation & $\begin{array}{l}-1.513 \\
(1.154)\end{array}$ & $\begin{array}{c}-1.328 \\
(1.084)\end{array}$ \\
\hline VC Backing & $\begin{array}{l}-0.527 \\
(0.719)\end{array}$ & $\begin{array}{l}-1.063 \\
(0.981)\end{array}$ \\
\hline Prone to IPO & $\begin{array}{l}-1.291 \\
(3.159)\end{array}$ & $\begin{array}{l}-1.120 \\
(3.149)\end{array}$ \\
\hline PRESTIGE-UNI & $\begin{array}{c}0.367 * * * \\
(0.101)\end{array}$ & $\begin{array}{c}0.376^{* * * *} \\
(0.101)\end{array}$ \\
\hline PRESTIGE-SC & $\begin{array}{c}0.372 * * * \\
(0.093)\end{array}$ & $\begin{array}{c}0.379 * * * \\
(0.094)\end{array}$ \\
\hline PRESTIGE-VC & $\begin{array}{c}3.040 * * \\
(1.273)\end{array}$ & $\begin{array}{c}3.144 * * \\
(1.285)\end{array}$ \\
\hline PRESTIGE-UW & $\begin{array}{c}4.830 * * * \\
(1.763)\end{array}$ & $\begin{array}{c}4.793 * * * \\
(1.761)\end{array}$ \\
\hline PRESTIGE-UNI $\times$ PRESTIGE-SC & $\begin{array}{c}-0.065^{* * * *} \\
(0.021)\end{array}$ & $\begin{array}{c}-0.064 * * * \\
(0.021)\end{array}$ \\
\hline PRESTIGE-UNI $\times$ PRESTIGE-VC & $\begin{array}{l}-0.407 \\
(0.257)\end{array}$ & $\begin{array}{l}-0.417 \\
(0.257)\end{array}$ \\
\hline PRESTIGE-UNI $\times$ PRESTIGE-UW & $\begin{array}{c}0.155 \\
(0.289)\end{array}$ & $\begin{array}{c}0.157 \\
(0.288)\end{array}$ \\
\hline University Ownership & $\begin{array}{c}0.772 \\
(1.053)\end{array}$ & - \\
\hline VC Syndicate & - & $\begin{array}{c}0.263 \\
(0.304)\end{array}$ \\
\hline Constant & $\begin{array}{c}10.573^{* * * *} \\
(3.141)\end{array}$ & $\begin{array}{c}10.586^{* * * *} \\
(3.138)\end{array}$ \\
\hline Observations & 254 & 254 \\
\hline R-squared & 0.464 & 0.460 \\
\hline Adjusted R-squared & 0.338 & 0.333 \\
\hline
\end{tabular}




\section{Table A10. Auxiliary regressions}

Model (1) is the first-stage regression in the Heckman selection model employed to estimate the Inverse Mills' Ration (IMR - Prone to IPO), as included in Model (1) of Table 5. This model estimates the probability to go public for the firms in our samples, combined with a random sample of 254 private biotech firms that did not go public between 1990 and 2009 but were similar to the companies in our sample according to nearest-neighbour propensity scores based on country dummies, industry dummies, size (total assets) and age. This first stage regression is estimated for all models in other tables. Model (2-4) are the Probit/OLS regressions for VC Affiliation, Prestige-VC and Prestige-UW. Residuals are employed in Model (1) of Table 5. These regressions are estimated for all models in other tables. VC Affiliation are the residuals after regressing the variable against University affiliation, PRESTIGE-UNI, PRESTIGE-SC, country and year control variables; Prestige-VC are the residuals after regressing the variable against: University affiliation, PRESTIGE-UNI, PRESTIGE-SC, country and year control variables; Prestige-UW are the residuals after regressing the variable against: University affiliation, PRESTIGE-UNI, PRESTIGE-SC, VC Backing, Prestige-VC, country and year control variables.

\begin{tabular}{|c|c|c|c|c|}
\hline & $\begin{array}{l}\text { (1) } \\
\text { Probability to } \\
\text { go public }\end{array}$ & $\begin{array}{c}(2) \\
\text { VC } \\
\text { Affiliation } \\
\end{array}$ & $\begin{array}{c}(3) \\
\text { PRESTIGE- } \\
\text { VC } \\
\end{array}$ & $\begin{array}{c}\text { (4) } \\
\text { PRESTIGE- } \\
\text { UW }\end{array}$ \\
\hline Firm size (Total assets) & $\begin{array}{c}0.057 * * * \\
(0.018)\end{array}$ & - & - & - \\
\hline Age & $\begin{array}{c}-0.029 * * * \\
(0.006)\end{array}$ & - & - & - \\
\hline Number of employees & $\begin{array}{c}0.223 * * * \\
(0.092)\end{array}$ & - & - & - \\
\hline University Affiliation & - & $\begin{array}{r}0.047 * * \\
(0.022)\end{array}$ & $\begin{array}{c}0.075^{* *} \\
(0.035)\end{array}$ & $\begin{array}{l}0.037 * \\
(0.020)\end{array}$ \\
\hline PRESTIGE-UNI & - & $\begin{array}{c}0.140 * * * \\
(0.031)\end{array}$ & $\begin{array}{c}0.090 * * * \\
(0.027)\end{array}$ & $\begin{array}{r}0.040^{* *} \\
(0.018)\end{array}$ \\
\hline PRESTIGE-SC & - & $\begin{array}{c}0.118 * * * \\
(0.026)\end{array}$ & $\begin{array}{c}0.018^{* * *} \\
(0.005)\end{array}$ & $\begin{array}{c}0.033 * * * \\
(0.010)\end{array}$ \\
\hline VC Backing & - & - & - & $\begin{array}{l}-0.007 \\
(0.032)\end{array}$ \\
\hline PRESTIGE-VC & - & - & - & $\begin{array}{c}0.073 * * * \\
(0.015)\end{array}$ \\
\hline Constant & $\begin{array}{c}0.032 \\
(0.359)\end{array}$ & $\begin{array}{c}-0.228 * * \\
(0.115)\end{array}$ & $\begin{array}{l}-0.014 \\
(0.024)\end{array}$ & $\begin{array}{c}0.008 \\
(0.017)\end{array}$ \\
\hline $\begin{array}{l}\text { Observations } \\
\text { (Pseudo) R-squared }\end{array}$ & $\begin{array}{c}508 \\
(0.098)\end{array}$ & $\begin{array}{c}254 \\
(0.120)\end{array}$ & $\begin{array}{c}254 \\
0.147\end{array}$ & $\begin{array}{c}254 \\
0.149\end{array}$ \\
\hline Adjusted R-squared & - & - & 0.116 & 0.117 \\
\hline
\end{tabular}

